\title{
Impacts of Urban Development on Precipitation in the Tropical Maritime Climate of Puerto Rico
}

\author{
Ángel Torres-Valcárcel ${ }^{1,2, *}$, Jonathan Harbor ${ }^{2}$, Cesar González-Avilés ${ }^{1}$ \\ and Ana Torres-Valcárcel ${ }^{1}$
}

1 COSUAM de Puerto Rico, 380 Roosevelt, Hato Rey, PR 00918, USA;

E-Mails: cesarnlily@gmail.com (C.G.-A.); towersdana@yahoo.com (A.T.-V.)

2 Department of Earth, Atmospheric, and Planetary Sciences, Purdue University, West Lafayette, IN 49706, USA; E-Mail: jharbor@ purdue.edu

* Author to whom correspondence should be addressed; E-Mail: atorresv09@gmail.com or atorresv@purdue.edu; Tel.: +1-787-674-3155; Fax: +1-787-250-6861.

Received: 5 December 2013; in revised form: 5 April 2014 / Accepted: 9 April 2014 /

Published: 22 April 2014

\begin{abstract}
Water is critical for sustaining natural and managed ecosystems, and precipitation is a key component in the water cycle. To understand controls on long-term changes in precipitation for scientific and environmental management applications it is necessary to examine whether local land use and land cover change (LULCC) has played a significant role in changing historical precipitation patterns and trends. For the small tropical island of Puerto Rico, where maritime climate is dominant, we used long-term precipitation and land use and land cover data to assess whether there were any detectable impacts of LULCC on monthly and yearly precipitation patterns and trends over the past century. Particular focus was given to detecting impacts from the urban landscape on mesoscale climates across Puerto Rico. We found no statistical evidence for significant differences between average monthly precipitation in urban and non-urban areas directly from surface stations, but, after subdividing by Holdridge Ecological Life Zones (HELZs) in a GIS, there were statistically significant differences $(\alpha=0.05)$ in yearly average total precipitation between urban and non-urban areas in most HELZs. Precipitation in Puerto Rico has been decreasing over the past century as a result of a decrease in precipitation during periods (months or years) of low rain. However, precipitation trends at particular stations contradict synoptic-scale long-term trends, which suggests that local land use/land cover effects are driving precipitation variability at local scales.
\end{abstract}


Keywords: precipitation; urban climate; spatial analysis; land use change

\section{Introduction}

As understanding and awareness of global climate changes have become more widespread, the local context of climate change has become an increasingly important issue for local governments, communities and institutions concerned about water supply, extreme weather events, and the economic and social consequences of changes in seasonal climate conditions and variability. In addition to large-scale global and regional drivers, there is an increasing body of literature that demonstrates that land use and land cover changes (LULCC) associated with anthropogenic activities such as urbanization and deforestation can impact local climates [1-7].

The effects of urbanization on local climate were first observed in Europe centuries ago (as cited in [8]) leading to the recognition of what is now known as the Urban Heat Island (UHI) effect. Although there has been considerable interest in evaluating temperature differences between urban areas and their rural surroundings [3,9-14], studies of variations in long-term precipitation due to urbanization $[6,15,16]$ or other changes in land use and land cover (LULC), such as deforestation/afforestation, are limited [4]. Deforestation can result in albedo increases, reduction of evapotranspiration (which changes sensible and latent heat partitioning), and rainfall interception [15]. Such changes resulting from deforestation have been linked to reductions in cloud cover and cloud formation height that could reduce precipitation $[4,15]$. On the other hand, afforestation (the creation of forests in places where they did not previously exist), although considered desirable in some respects, may lead to unintended results depending on local conditions and processes [4]. This reinforces the importance of studying climate responses to LULCC in a variety of environmental settings.

Much of the existing work examining the impacts of LULCC on local climates has focused on mid-latitude continental sites. However, the complex dynamics of LULCC-climate mechanisms vary from place to place and between land-cover classes [4]. Further, it is known that similar land cover changes induce different climate feedbacks at different latitudes [17,18]. There is comparatively little climate research in tropical settings and on small tropical islands [15,19]. Such work is particularly challenging because of a typical scarcity of long-term data and low data densities [19]. Further, the traditional coarse resolution grids designed for climate assessment in continental settings, including generalized assumptions of similar vegetation and land cover types, are not well suited for studying the scale and heterogeneity of small regions. However, LULCC may be an important component of climate change on small tropical islands, particularly given widespread historical vegetation changes associated with agricultural transitions and rapid urbanization, including coastal development related to tourism. However, the weather and climate of tropical islands is also affected by strong maritime influences as well as synoptic scale phenomena, such as El Niño and the North Atlantic Oscillation.

Fortunately, the existence of long-term databases and a relatively high density of observation stations in Puerto Rico may provide unique opportunities to assess climate variations on a small tropical island and to detect and isolate any regional drivers of local climate conditions. A variety of climate studies have been undertaken in Puerto Rico addressing temperature regionalization [20,21], 
precipitation regionalization [20-25], rainfall classification [22,26,27], regional synoptic influences [24], urban heat islands [8,12], and using observation and numerical experiments [8,12,28] (Table 1). The work presented here characterizes precipitation patterns in Puerto Rico and provides a first attempt to assess in detail the question of whether long-term spatial and temporal changes in precipitation reflect variations related to local land use and land cover changes. We discuss how global and regional synoptic phenomena influence Puerto Rico's climate and then analyze a century of data with a range of methods to test hypotheses relating LULCC to precipitation changes and differences.

Table 1. Summary of previous published precipitation research for Puerto Rico.

\begin{tabular}{|c|c|c|c|c|}
\hline Article & \# Stations & Period & Method & Remarks \\
\hline Ray, 1933 [29] & 46 & $1899-1932$ & $\begin{array}{c}\% \text { departures from } \\
\text { normal }\end{array}$ & $\begin{array}{l}\text { The smaller the average the } \\
\text { greater the year by year variation } \\
\text { and vice versa. Gradual decrease } \\
\text { in precipitation preceded drought } \\
\text { years. Wet years come in pairs }\end{array}$ \\
\hline $\begin{array}{c}\text { Ewel and Whitmore, } \\
1973[20]\end{array}$ & 143 & $1900-1969$ & $\begin{array}{l}\text { Holdridge } \\
\text { Ecological Life } \\
\text { Zones }\end{array}$ & $\begin{array}{l}\text { Microclimate classification based } \\
\text { on biotemperature, humidity and } \\
\text { precipitation. Various lengths } \\
\text { of data, longest individual period } \\
15 \text { years }\end{array}$ \\
\hline $\begin{array}{c}\text { Pagan-Trinidad, } \\
1984 \text { [26] }\end{array}$ & 10 & $1971-1983$ & $\begin{array}{l}\text { Statistics, } \\
\text { frequencies, } \\
\text { probability }\end{array}$ & $\begin{array}{l}\text { Spatial and temporal variability } \\
\text { of storm rainfall (storm duration, } \\
\text { rain intensity) Geographic } \\
\text { consideration }\end{array}$ \\
\hline $\begin{array}{c}\text { Carter and Elsner, } \\
1996[22]\end{array}$ & 22 & $1973-1988$ & EOF & $\begin{array}{l}\text { Diurnal rainfall regionalization } \\
\text { ( } 6 \text { regions), No land cover } \\
\text { change considered. The eastern } \\
\text { part showed low hourly } \\
\text { variability while the western part } \\
\text { showed high hourly variability. }\end{array}$ \\
\hline $\begin{array}{c}\text { Carter and Elsner, } \\
1997[23]\end{array}$ & 22 & 1973-1988 & $\begin{array}{c}\text { EOF, Statistical } \\
\text { Classification Tree }\end{array}$ & $\begin{array}{l}\text { Regionalization ( } 6 \text { regions), } \\
\text { No land cover considered }\end{array}$ \\
\hline $\begin{array}{l}\text { Malmgren et al., } \\
\quad 1998 \text { [30] }\end{array}$ & 5 & 1901-1995 & $\begin{array}{l}\text { Station data, SOI } \\
\text { and NAO indexes, } \\
\text { Burnaby test }\end{array}$ & $\begin{array}{l}\text { Regional synoptic phenomena } \\
\text { rainfall and temperature } \\
\text { influence over PR }\end{array}$ \\
\hline $\begin{array}{c}\text { Malmgren and } \\
\text { Winter } 1999 \text { [24] }\end{array}$ & 18 & 1960-1990 & $\begin{array}{l}\text { Rotated PCA and } \\
\text { Neural Networks }\end{array}$ & $\begin{array}{l}\text { Seasonal Rainfall } \\
\text { Regionalization ( } 4 \text { zones) } \\
\text { In three zones precipitation } \\
\text { increased consecutively at each } \\
\text { season and peaked in the Fall, in } \\
\text { one zone it peaked in the summer. }\end{array}$ \\
\hline Larsen 2000 [31] & 12 & 1900-2000 & $\begin{array}{l}\text { Drought Index, } \\
\text { rainfall } v s \text {. stream } \\
\text { flow comparison }\end{array}$ & $\begin{array}{l}\text { Interregional and intraregional } \\
\text { analysis. Precipitation decreasing } \\
\text { in the Caribbean and PR }\end{array}$ \\
\hline $\begin{array}{l}\text { Comarazamy, } \\
2001[32]\end{array}$ & 15 & April 1998 & Mesoscale model & $\begin{array}{l}\text { April } 1998 \text { wind and rainfall } \\
\text { simulation San Juan city } \\
\text { precipitation was under } \\
\text { predicted, The most accurate } \\
\text { results occurred at higher } \\
\text { elevations were uplift from } \\
\text { northeasterly winds interacts with } \\
\text { steeper slopes }\end{array}$ \\
\hline $\begin{array}{l}\text { Van der Molen, } \\
2002 \text { [17] }\end{array}$ & $\begin{array}{l}1 \text { portable }+ \text { various } \\
\text { on site instruments }\end{array}$ & May 1997-May 1998 & $\begin{array}{c}\text { Field observations, } \\
\text { mesoscale model }\end{array}$ & $\begin{array}{l}\text { Analyzed deforested areas, } \\
\text { measured forest reservation } \\
\text { forests, Urban land cover not } \\
\text { considered }\end{array}$ \\
\hline $\begin{array}{l}\text { Chen and Taylor } \\
2002 \text { [33] }\end{array}$ & $>100$ & $\begin{array}{c}\text { January } \\
\text { 1921-December } 1986\end{array}$ & EOF/COLA AGCM & $\begin{array}{l}\text { EOF first mode from Caribbean } \\
\text { early precipitation strongly } \\
\text { correlates with ENSO }+1\end{array}$ \\
\hline
\end{tabular}


Table 1. Cont.

\begin{tabular}{|c|c|c|c|c|}
\hline Article & \# Stations & Period & Method & Remarks \\
\hline Daly et al., 2003 [21] & 47 Temp; 108 Precip. & 1963-1995 & PRISM & $\begin{array}{l}\text { No land cover change } \\
\text { considered. Spatial variation of } \\
\text { rainfall was associated to } \\
\text { elevation, upslope exposure to } \\
\text { winds carrying moisture and } \\
\text { distance to coastline. }\end{array}$ \\
\hline Neelin et al., 2006 [14] & Gridded data & $\begin{array}{l}1970-2003 \\
1950-2002 \\
1951-2000\end{array}$ & $\begin{array}{l}\text { Satellite databases, } \\
\text { gridded station data, } \\
\text { Precipitation models }\end{array}$ & $\begin{array}{l}\text { Higher model agreement in the } \\
\text { Caribbean and Central } \\
\text { American of Summer drying } \\
\text { trend and increase in heavy rain } \\
\text { events }\end{array}$ \\
\hline $\begin{array}{l}\text { Ramírez-Beltrán et al., } \\
2007 \text { [27] }\end{array}$ & 6 & $1901-2001$ & Statistical models & $\begin{array}{l}\text { Logistic Regression; } \\
\text { Categorical Classification of } \\
\text { precipitation events, no land } \\
\text { cover considered }\end{array}$ \\
\hline Jury et al., 2007 [25] & $\begin{array}{l}35 \text { regional } \\
(7 \text { from } \mathrm{PR})\end{array}$ & $1951-1981$ & Factor Analysis & $\begin{array}{l}\text { Caribbean basin rainfall } \\
\text { regionalization }\end{array}$ \\
\hline $\begin{array}{l}\text { Nyberg et al., } \\
2007 \text { [34] }\end{array}$ & $\begin{array}{c}4 \text { cores } \\
\text { (paleo study) }\end{array}$ & $1730-2005$ & $\begin{array}{l}\text { Coral cores, wind } \\
\text { shear records, } \\
\text { artificial neural } \\
\text { networks }\end{array}$ & $\begin{array}{l}\text { Historical Caribbean basin } \\
\text { hurricane activity }\end{array}$ \\
\hline
\end{tabular}

\begin{tabular}{|c|c|c|c|c|}
\hline $\begin{array}{l}\text { Comarazamy and } \\
\text { González, } 2008 \text { [28] }\end{array}$ & 15 & 1993 and 1998 & Mesoscale model & $\begin{array}{l}\text { Early wet season simulation, No } \\
\text { land cover change considered }\end{array}$ \\
\hline $\begin{array}{l}\text { Harmsen et al. } \\
\quad 2009[35]\end{array}$ & 3 & $1960-2000$ & $\begin{array}{l}\text { GCM downscaling, } \\
\text { trends, linear } \\
\text { regression }\end{array}$ & $\begin{array}{l}\text { Precipitation deficits scenarios } \\
\text { resulted in crop yield reduction } \\
\text { and wetter wet seasons and drier } \\
\text { dry seasons }\end{array}$ \\
\hline Jury, 2009 [36] & $\begin{array}{c}\text { Interpolated data from } \\
17,000 \text { Caribbean } \\
\text { stations to grids }\end{array}$ & 1979-2000 & $\begin{array}{l}\text { Observations, } \\
\text { Reanalysis, } \\
\text { Satellite, and } \\
\text { Coupled } \\
\text { Model Data }\end{array}$ & $\begin{array}{l}\text { Evaluated ability of different } \\
\text { products to represent mean } \\
\text { annual Caribbean rainfall. } \\
\text { Caribbean rainfall is projected } \\
\text { to decline around } 20 \% \text { over the } \\
\text { next } 100 \text { years. }\end{array}$ \\
\hline $\begin{array}{l}\text { Jury and Sanchez, } \\
2009[37]\end{array}$ & 60 (rain gages) & 1979-2005 & $\begin{array}{l}\text { NCAR, statistics of } \\
\text { daily rainfall }\end{array}$ & $\begin{array}{l}\text { Most flood events in Puerto } \\
\text { Rico occurred in May, August } \\
\text { and September }\end{array}$ \\
\hline $\begin{array}{l}\text { Comarazamy et al., } \\
2010[38]\end{array}$ & $\begin{array}{l}\text { N/A Atlas Mission } \\
\text { Observations }\end{array}$ & 10-20 February 2004 & Mesoscale model & $\begin{array}{l}\text { Mixed Urban and Natural } \\
\text { adjustments yielded more } \\
\text { accurate results. U-R } \\
\text { temperature up to } 2.5^{\circ} \mathrm{C} \\
\text { difference. Increased } \\
\text { precipitation downwind } \\
\text { Southwest San Juan } \\
\end{array}$ \\
\hline $\begin{array}{l}\text { Angeles et al., } \\
2010 \text { [39] }\end{array}$ & $\begin{array}{c}\text { NOAA data at } 1^{\circ}, \\
\text { NCEP } 2.5^{\circ} \text { reanalysis } \\
\text { data, and NOAA- } \\
\text { NCEP CPC merged } \\
\text { analysis } \\
\text { (Xie-Arkin) dataset }\end{array}$ & $\begin{array}{c}\text { Climatology } \\
1983-2004 \\
\text { Simulated } \\
\text { July } 2002 \text { and July } \\
2003\end{array}$ & RAMS & $\begin{array}{l}\text { Built a Caribbean Bimodal } \\
\text { index. Mid-Summer Drought } \\
\text { over Puerto Rico related to } \\
\text { Saharan dust aerosol particles } \\
\text { and vertical wind shear. }\end{array}$ \\
\hline $\begin{array}{l}\text { Comarazamy and } \\
\text { Gonzalez, } 2011[40]\end{array}$ & $\begin{array}{l}\text { NCEP } 2.5^{\circ} \text { reanalysis } \\
\text { data, } 5 \text { surface } \\
\text { stations }\end{array}$ & $\begin{array}{l}\text { April-June } \\
\text { 1955-1959 and } \\
\text { April-June } \\
\text { 2000-2004 }\end{array}$ & RAMS & $\begin{array}{l}\text { Larger scale climate impacts } \\
\text { induce changes in wind } \\
\text { magnitude and direction, cloud } \\
\text { base heights, and total column } \\
\text { liquid water content resulting in } \\
\text { total surface accumulated } \\
\text { precipitation changes. }\end{array}$ \\
\hline
\end{tabular}




\section{Study Area}

Puerto Rico is the smallest of the Greater Antilles located at $18^{\circ} \mathrm{N}$ latitude and $66^{\circ} \mathrm{W}$ longitude in the eastern part of the Caribbean basin, and one of the world's biodiversity hotspots [41]. Puerto Rico is $160 \mathrm{~km}$ long by $50 \mathrm{~km}$ wide and includes several smaller islands [42]. The main island has a Central Mountain Range running east west, the Luquillo Mountains in the northeast and karst topography dominates in the northwest. Fifty-three percent of the island's terrain is mountainous, $25 \%$ are plains and $20 \%$ hills [42]. Wetter regions occur on the northern side of mountains that shield the southern drier region from Atlantic moisture. Precipitation in Puerto Rico shows a yearly cycle with a bimodal distribution (two maxima) peaking first in May as the wet season starts followed by the "Mid Summer Drought" [43] and then a second and biggest peak in October-November, consistent with patterns across Central America and the Caribbean Basin [25,33,36,39,44,45]. Mean annual temperatures range from $22{ }^{\circ} \mathrm{C}$ to $25{ }^{\circ} \mathrm{C}$ [42]. Six distinctive Holdridge Ecological Lifezones (HELZ; [46]) are found in Puerto Rico (HELZ are defined by humidity, annual precipitation and potential evapotranspiration) ranging from Rain Forest (precipitation over $4000 \mathrm{~mm} / \mathrm{year}$ ) to Dry Forest (precipitation below $900 \mathrm{~mm} /$ year) [30]; however 99\% of the island is covered by Moist Forest, Dry Forest, and Wet Forest HELZ (Figure 1). Seasonal temperature trends and long-term trends in mean annual temperature in Puerto Rico generally track equivalent trends in Global Land and Sea Surface Temperatures [11].

Figure 1. Puerto Rico's Holdridge Ecological Lifezones, Areas of Interest, and Weather stations. HELZ data from US Forest Service, urban areas data from Puerto Rico GAP 2004, weather stations data from NOAA Historical Climate Network.

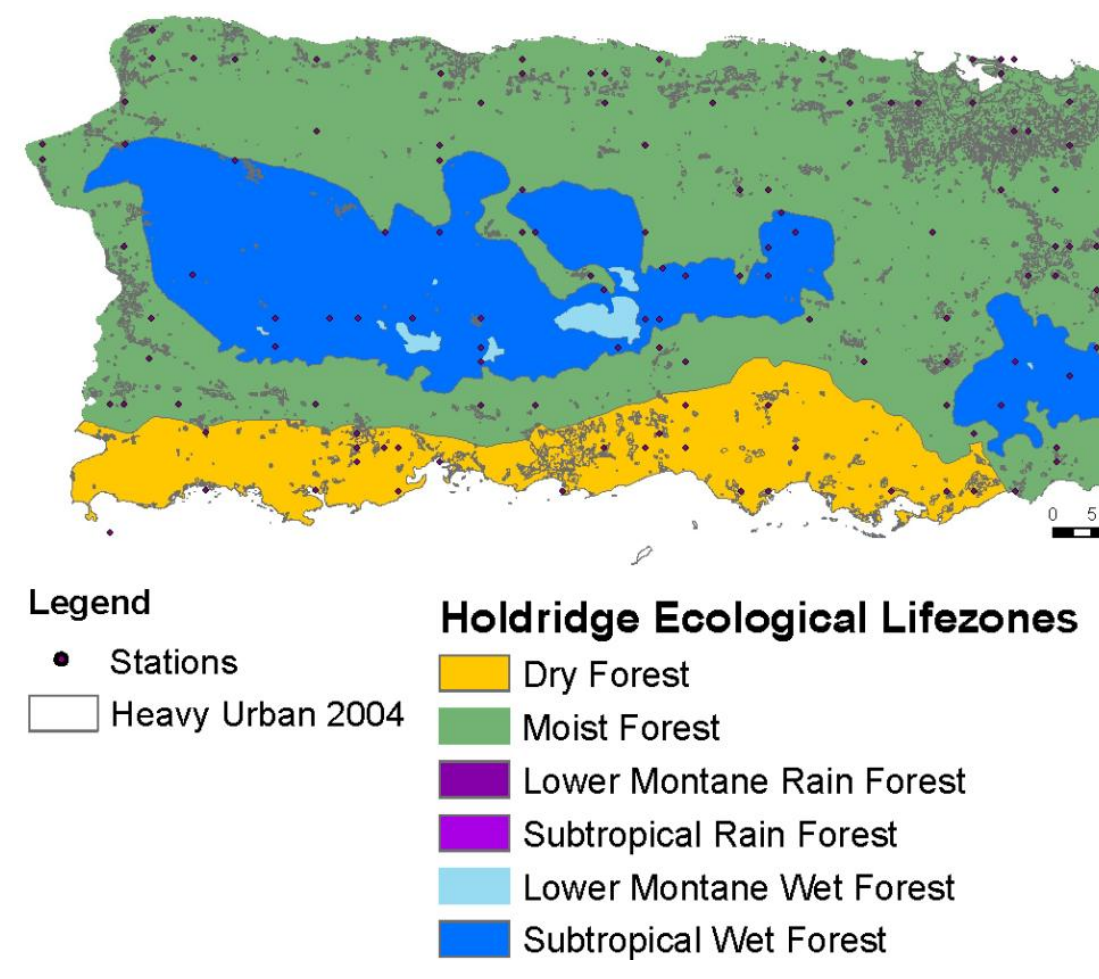

Pagán-Trinidad [26] identified several major forcings for precipitation in Puerto Rico that are a function of season and location: 
- Orographic - related to mechanical uplift of air caused by mountains. Mostly associated with persistent easterly Trade Winds in Eastern Puerto Rico during the Dry Season.

- Convection - caused by differential land heating, including triggering by urban landscapes

- Tropical Systems - easterly waves and synoptic scale systems bring precipitation for all or most of the island, especially during Hurricane season (July-November)

- Cold fronts - westerly systems from northern latitudes dominate Western Puerto Rico during late Wet Season and Dry Season

This basic classification is useful for understanding the primary synoptic settings for precipitation episodes that underlie spatial and temporal variations in precipitation. In addition, other land biological, chemical and physical features or processes can affect variables such as temperature, humidity, surface roughness and aerosols that are related to precipitation. Temperatures affect vertical velocity and convective potential related to cloud formation and rain intensity. Aerosols affect water droplet formation and cloud formation potential. Surface roughness can increase convergence and cloud formation potential, inducing local precipitation. Land processes such as evapotranspiration, energy fluxes and cloud formation can also drive local precipitation, and evapotranspiration, water content, and humidity affect the availability of water for cloud formation [40].

\section{Previous Precipitation Studies in Puerto Rico}

Most long-term studies of Puerto Rico's climate have used a limited number of stations, because relatively few stations have a long-term record [30,31], while shorter-term studies make use of the fact that more stations have data available for specific shorter periods, especially since 1960 [15,21-29,32,35,37]. Long-term studies suggest that precipitation has been decreasing in the Caribbean since the 1970s and that droughts in Puerto Rico are periodic [31]. Some studies predict that global warming should result in an increase in negative precipitation anomalies during the summer (June-August), increased dry season duration and more frequent heavy rain events in the Caribbean [14,35,47]. Overall, rainfall in most subtropical areas, including the Caribbean, is projected to decline by around $20 \%$ over the next 100 years [36]. Other studies suggest that hurricane frequency in the Caribbean is returning to a long-term average level instead of increasing due to global warming [40].

\subsection{Precipitation Studies Related to LULC and LULCC in Puerto Rico}

Observational as well as computer-modeling studies have been used to assess impacts of LULC and LULCC on Puerto Rico's precipitation for individual storm events as well as longer-term climate. Pagán-Trinidad [26] assessed precipitation origin and rain intensity variation across different landscapes of the island, including urban settlements, and attempted to classify different rainfall origins and associate them with island regions and landscapes. More recently, climate models and numerical experiments have focused primarily on the impacts of urbanization on meteorological variables around San Juan [28,32,38], on the impacts of coastal deforestation [15,38], localized precipitation increases caused by urban effects from San Juan, and Comarazamy and González, 2011 [40] studied both isolated and combined effects of LULCC and large-scale climate 
change on precipitation for Northeastern Puerto Rico. However several modeling studies have been limited primarily to validation efforts and have large errors and low accuracy for urban areas [32,38].

\subsection{Rainfall Mapping and Regionalization Studies}

Several studies have attempted to map precipitation around the island or the Caribbean basin using a variety of methods and techniques (Table 1). Ewel and Whitmore [20] used long-term station data, vegetation characteristics and forest types to define climate provinces for Puerto Rico. Carter and Elsner [22] used factor analysis with Partially Adaptive Classification Trees to regionalize precipitation. Malmgren and Winter [24] combined artificial neural networks with Principal Components Analysis (PCA) to map precipitation regions in Puerto Rico. Unfortunately, no stations from the western half of Puerto Rico were included in the study, and this is where both the driest region and one of the wettest regions of the island are located. Jury et al. [25] used the same method to regionalize rainfall for the entire Caribbean basin. An alternative approach, Parameter-elevation Regressions on Independent Slopes Model (PRISM) used elevation models, upslope exposure to winds carrying moisture, distance to the coastline weather station data and physical parameters for climate mapping simulation [21]. The work reported in Daly et al. [21] was the most recent attempt to map the climate (temperature and precipitation) of Puerto Rico using modern sophisticated methods based on natural landscape properties, but not LULC features.

\subsection{Subregional Precipitation Zones and the Impacts of ENSO and NAO}

Several studies have suggested the existence of sub-regional precipitation zones or clusters based on rain patterns around the Caribbean. Puerto Rico is consistently placed in the southeastern cluster, characterized by bimodal seasonal precipitation with $80 \%$ of the precipitation falling during summer (May-December) [25]. Two major regional atmospheric phenomena are known to have an important influence on the Caribbean and Puerto Rican climate: El Niño Southern Oscillation (ENSO) and the North Atlantic Oscillation (NAO) [30] (summarized in Table 2). Chen and Taylor [33] found strong correlations between the Caribbean early precipitation and wintertime equatorial Pacific anomalies in years of ENSO decline (El Niño +1 year). According to Malmgren et al. [30] ENSO has no observable effects on Puerto Rico's yearly precipitation. Seasonally, ENSO has a positive effect on the southeastern Caribbean, which includes the eastern half of Puerto Rico [25].

The NAO is more influential than ENSO in the Southeastern Caribbean where Puerto Rico is located [25] and the stronger the NAO the lower the precipitation [30]. Monthly and seasonal precipitation respond differently to NAO in the Southeastern Caribbean, although particular months may show positive correlation with $\mathrm{NAO}$ and higher precipitation. In general, there is a negative correlation between NAO and precipitation in most Caribbean subregions [25]. Seasonal influence is critically important in the Southeastern Caribbean because most of the precipitation falls during the summer [25]. Simulations with a mesoscale model using the Parallel Climate Model (PCM) to project future climate changes in Puerto Rico under the IPCC's Business as Usual (BAU) Scenario showed that the Southern Oscillation Index (SOI) and NAO have important controls on annual Caribbean rainfall variability [47]. 
Table 2. Annual effects of El Niño Southern Oscillation (ENSO) and North Atlantic Oscillation (NAO) on Puerto Rico's precipitation.

\begin{tabular}{|c|c|c|c|c|c|c|}
\hline \multirow{2}{*}{ Climate Variable } & \multicolumn{3}{|c|}{ ENSO Effect } & \multicolumn{3}{|c|}{ NAO Index } \\
\hline & High & Average & Low & High & Average & Low \\
\hline $1990-1995^{\text {a }}$ & $a$ & $a$ & $a$ & $a$ & $a$ & $a$ \\
\hline $\begin{array}{c}\text { Total Precipitation } \\
\text { Average Precipitation }\end{array}$ & $\begin{array}{c}\text { No effect }+ \\
\text { No effect }\end{array}$ & $\begin{array}{c}\text { No effect }+ \\
\text { No effect }\end{array}$ & $\begin{array}{c}\text { No effect }+ \\
\text { No effect }\end{array}$ & $\begin{array}{l}<\text { average * } \\
\text { <average }\end{array}$ & $\begin{array}{l}\text { No effect } * \\
\text { No effect }\end{array}$ & $\begin{array}{l}\text { >average * } \\
\text { >average }\end{array}$ \\
\hline $\begin{array}{l}\text { Median Precipitation } \\
\qquad 1951-1981^{\mathrm{b}}\end{array}$ & $\begin{array}{c}\text { No effect }+ \\
b\end{array}$ & $\begin{array}{c}\text { No effect }+ \\
b\end{array}$ & $\begin{array}{c}\text { No effect }+ \\
b\end{array}$ & $\begin{array}{c}<\text { average }+ \\
b\end{array}$ & $\begin{array}{c}\text { No effect }+ \\
b\end{array}$ & $\begin{array}{c}\text { >average }+ \\
b\end{array}$ \\
\hline Monthly Total Precipitation & No effect + & No effect + & No effect + & >average & >average & <average \\
\hline $\begin{array}{c}\text { Monthly Average Precip. } \\
\text { Seasonal Precipitation }\end{array}$ & $\begin{array}{l}\text { No effect } * \\
\text { >average }\end{array}$ & $\begin{array}{l}\text { No effect } * \\
>\text { average }\end{array}$ & $\begin{array}{l}\text { No effect } * \\
\text { >average }\end{array}$ & $\begin{array}{l}\text { >average * } \\
\text { <average }\end{array}$ & $\begin{array}{l}>\text { average } * \\
\text { <average }\end{array}$ & $\begin{array}{l}<\text { average } * \\
>\text { average }\end{array}$ \\
\hline
\end{tabular}

a Malmgren et al. [30]; ${ }^{\mathrm{b}}$ Jury et al. [25] Effects are based on observations unless otherwise indicated;

* are effects deduced from the paper narrative; and + are effects described as expected in the paper narrative.

\section{Data and Methods}

The purpose of this study was to assess whether LULC and LULCC have a significant impact on long-term precipitation statistics in Puerto Rico over the past century. Within this scope, a primary research question was whether urban impacts could be detected in long-term monthly precipitation records in Puerto Rico. Precipitation data for LULC types of key local interest, such as "urban" and "regenerated forest" areas, were evaluated against data for nonurban areas within the same Holdridge Ecological Life Zone (HELZ) (Figures 2 and 3); comparing data within HELZ was found to be a useful approach in understanding LULCC impacts on temperature [13] and, thus, it is reasonable to apply a similar approach for the study of precipitation. To examine how various climate study methods help in understanding the role of LULCC on precipitation we used both simple and more sophisticated research methods, including descriptive and inferential statistics (Analysis of Variance; ANOVA), traditional climate research methods like trends analysis, and Geographic Information Systems (GIS).

Figure 2. Average and Median Precipitation by Month for Puerto Rico's HELZ, 1900-2007.

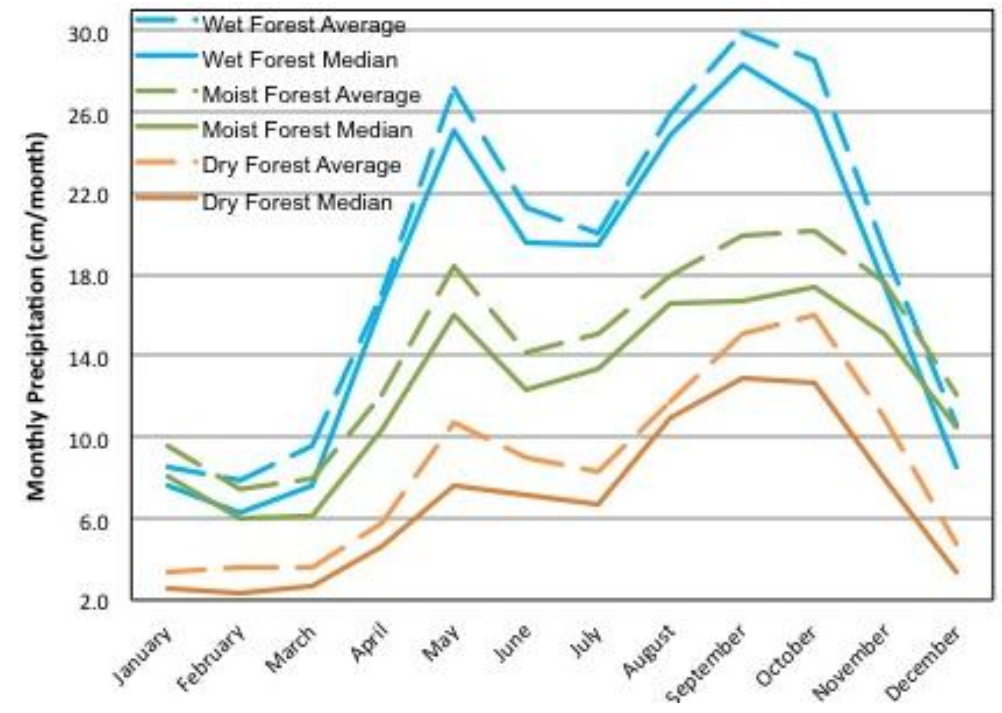




\subsection{Precipitation and Land Use/Land Cover Data}

Monthly raw total precipitation observation data for 1900-2007 from 139 stations in Puerto Rico were provided by NOAA and were used for geographical analysis. The Helmer et al. [41] Puerto Rico Forest Type and Land Cover digitized map (for 1992) and the Puerto Rico Gap Analysis Project map from Gould et al. [42] (for 2004) were provided by the United States Forest Service's Institute of Tropical Forestry in Puerto Rico. The 1992 Map used $30 \mathrm{~m}$ grid spacing and 33 land use/cover classes while the 2004 Map used $15 \mathrm{~m}$ grid spacing and 72 land use/cover classes. Separate analysis about Urban vs. Non Urban precipitation was done independently on each map to assess differences at current conditions. As urban land cover definition was different for each map, only internal differences were analyzed and no direct comparisons were made between the 1992 and 2004 maps.

Figure 3. Decadal trends in Average and Median Monthly Precipitation for Puerto Rico's HELZ.

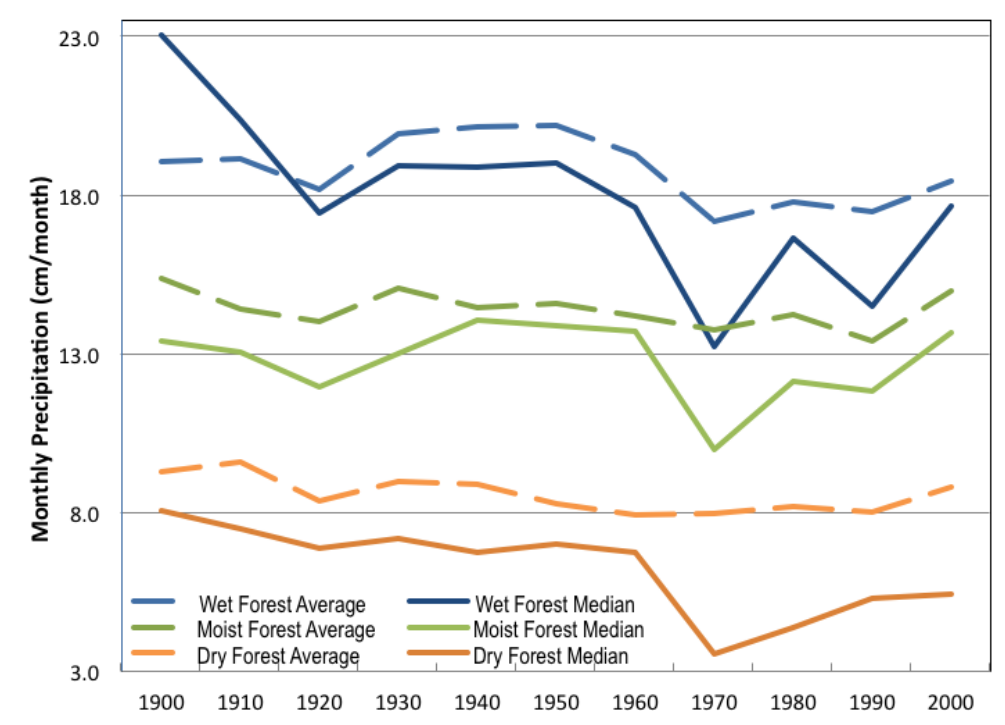

\subsection{Puerto Rico Holdridge Ecological Lifezones Data}

The US Forest Service's Institute of Tropical Forestry in Puerto Rico provided Puerto Rico HELZ digital maps from the Puerto Rico Gap Analysis Project [42] that were used in this study. There are six HELZs in Puerto Rico; Subtropical Dry Forest (DF), Subtropical Moist Forest (MF), Subtropical Wet Forest (WF), Subtropical Lower Montane Wet Forest (LMWF), Subtropical Lower Montane Rain Forest (LMRF), and Subtropical Rain Forest (RF). The main three HELZ are DF, WF and MF, which together cover $99 \%$ of the island. The DF is the smallest of the main HELZs, covering $14 \%$ of the island and has the highest temperatures and lowest precipitation. The MF is the largest HELZ and covers $62 \%$ of the island and has medium level temperatures and precipitation. The WF covers $23 \%$ of the island and has the lowest temperatures and highest precipitation. The remaining three HELZ cover less than $1 \%$ of the island and are mostly limited to the Rain Forest reservation. For simplification and convenience they were not analyzed as independent regions but considered part of the Rain Forest Reserve or the Wet Forest HELZ, however, all station data were used for map creation. 


\subsection{Statistical Methods}

Since average quantities are heavily influenced by extreme values, average and median precipitation curves were plotted together to track occurrence of higher precipitation periods. We expect average and median curves to be very similar if data follows a symmetric distribution; however if higher precipitation periods dominate the frequency of periods then the median would be well above the average and if lower precipitation periods dominate the median would be well below the average.

Statistical analyses of the observational data focused on testing for precipitation differences between HELZ and between LULC classes within HELZ. To examine for possible precipitation differences associated with HELZ or land use, ANOVA was used to detect monthly, seasonal and decadal differences between regions. Digital maps were generated from individual station records by interpolating values and provided a visual representation of spatial patterns of precipitation.

In addition, the coefficient of variation, $\mathrm{C}_{V}$ (standard deviation divided by mean) for each station was computed for different time periods. The $\mathrm{C}_{V}$ estimates the variability of the data relative to its magnitude and is a useful tool to find spatial patterns of variability and change. The $\mathrm{C}_{V}$ was mapped using Arc Map 10 Spatial Analyst Tool using the Inverse Distance Weighted (IDW) interpolation method to assess spatial patterns of change. The IDW method interpolates spatial values as a function of the inverse of the distance between stations and suitable for climate mapping. Preliminary test maps were generated using different settings of the IDW tool to assess its reliability to represent the broad island wide patterns of rainfall already known in Puerto Rico, such as the regions with the highest and lowest precipitation. IDW settings were kept at default values and we tested different grid sizes to find the best match with the highest resolution layer at $15 \mathrm{~m}$ by $15 \mathrm{~m}$. Due to processing power limitations the grid sizes used in the analysis were set at $270 \mathrm{~m}$ and $100 \mathrm{~m}$.

Simple linear regression was used to analyze precipitation time series linear trends in different time periods using a linear least squares fit model, given that the data fits a normal distribution. Data were analyzed in different time periods; the entire record of over a century of data (1900-2007); 30 year periods (1900-1929, 1930-1959, 1960-1989, and 1990-2007), PRISM (1963-1995) and Reanalysis (1979-2005). The later period of 1990-2007 is shorter including only the data available for a full year at the beginning of this study, the PRISM period is frequently used for studies because of the high amount of station/year data and the Reanalysis period is when atmospheric grid became available until the latest year available at the beginning of this study. We considered PRISM and Reanalysis periods to evaluate how quantitatively distinctive they are from the other periods and how selecting them could have altered our results. However, only the 30-year periods were considered for ANOVA although all periods were analyzed for trends.

\subsection{GIS Methods}

ARC MAP GIS 9.2 was used to select climate stations inside the HELZs and specific land use classes using the 1992 and 2004 LULC maps. Only stations located inside the main three HELZ were considered for regional ANOVA analysis but all (139) stations were used to generate GIS interpolated maps. From the 1992 LULC map, the "urban and barren" land cover class was considered as "urban" while in the 2004 LULC map, the "High Density Urban" land cover class was selected as "urban" 
(Figures 4 and 5). Different biomes respond differently to impervious surfaces and so ecological contexts are important [11]. To control for any local ecological variation, "urban" regions were analyzed in their HELZ against their respective "non urban" areas to avoid any misinterpretation of the results due to stations located in different HELZ. The two urban land covers from the 1992 and the 2004 maps were coded for the corresponding HELZ as U[HELZ]92 and U[HELZ]04 respectively.

Figure 4. Puerto Rico 1992 Land Cover Map from Helmer et al. [41].

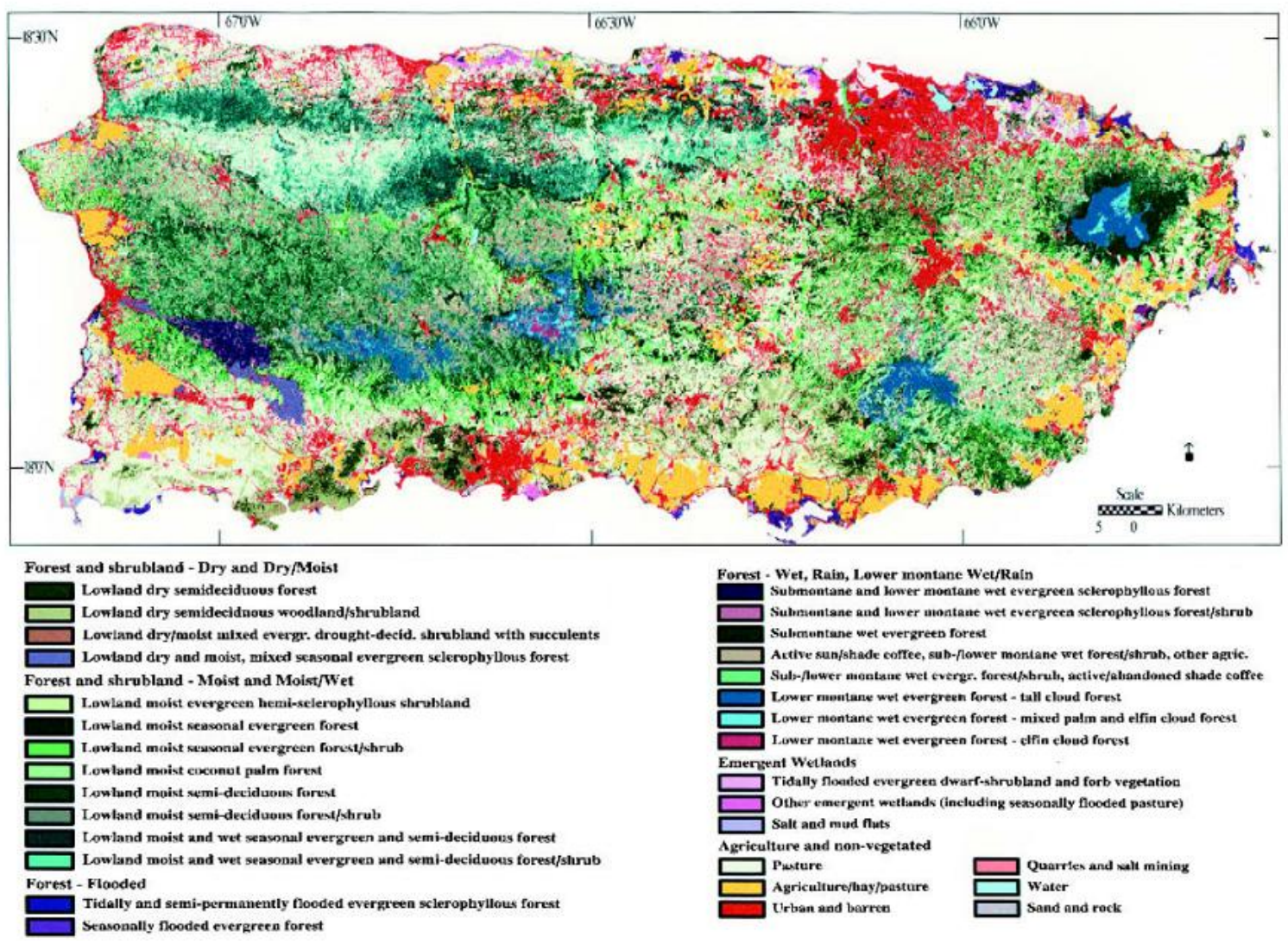

Reproduced by permission of the College of Arts and Sciences, University of Puerto Rico at Mayagüez.

Several data subsets were used for the analysis of urban regions because of the use of two different station regional selection methods (Type A and Type B). Each data subset was statistically analyzed in separate groups to meet statistical independence assumption criteria. The ARC MAP GIS 9.2 default "intersect" data selection method considered only stations contained inside the urban LULC and was classified as "Type A Selection", the other method (Type B Selection) used 30, 60, and 90 m radius buffers around each station. Urban areas from A selection were coded 1992 A (U1992A) and 2004 A (U2004A), urban areas from the B selection were coded 1992 B (U1992B) and 2004 B (U2004B). As the number of urban stations increased by the increased buffer size, they were subtracted from the Non Urban counterpart and new averages were computed for both, the new urban region with additional stations and the new non-urban station with subtracted stations (Tables 3 and 4).

The DF was subdivided into Urban Dry Forest by LULC map and Selection type into (UDF92A, UDF92B, UDF04A and UDF04B) which included all urban stations from the DF and Dry Forest Non Urban (DFNU92A, DFNU92B, DFNU04A, and DFNU04B), which excluded all urban stations from the DF. The MF was subdivided into Moist Forest (MF) consisting of all stations including those 
selected as "urban" for analysis purposes between the three HELZ, the Moist Forest Non Urban Selection A (MFNUA) and B (MFNUB) excluded urban stations for each and 1992 and 2004 LULC maps coded by selection type A or B (MFNU92A, MFNU92B, MFNU04A, and MFNU04B). The WF was subdivided into Wet Forest Reserve (WFR) located at the base of the Rain Forest Reserve, the Unregenerated Wet Forest at the east (URWF) and the Regenerated Wet Forest in the West (RWF), where natural reforestation has occurred.

Figure 5. Puerto Rico GAP 2004 Land Cover Map from Gould et al. [42]. (Figure courtesy of the U.S. Geological Survey).

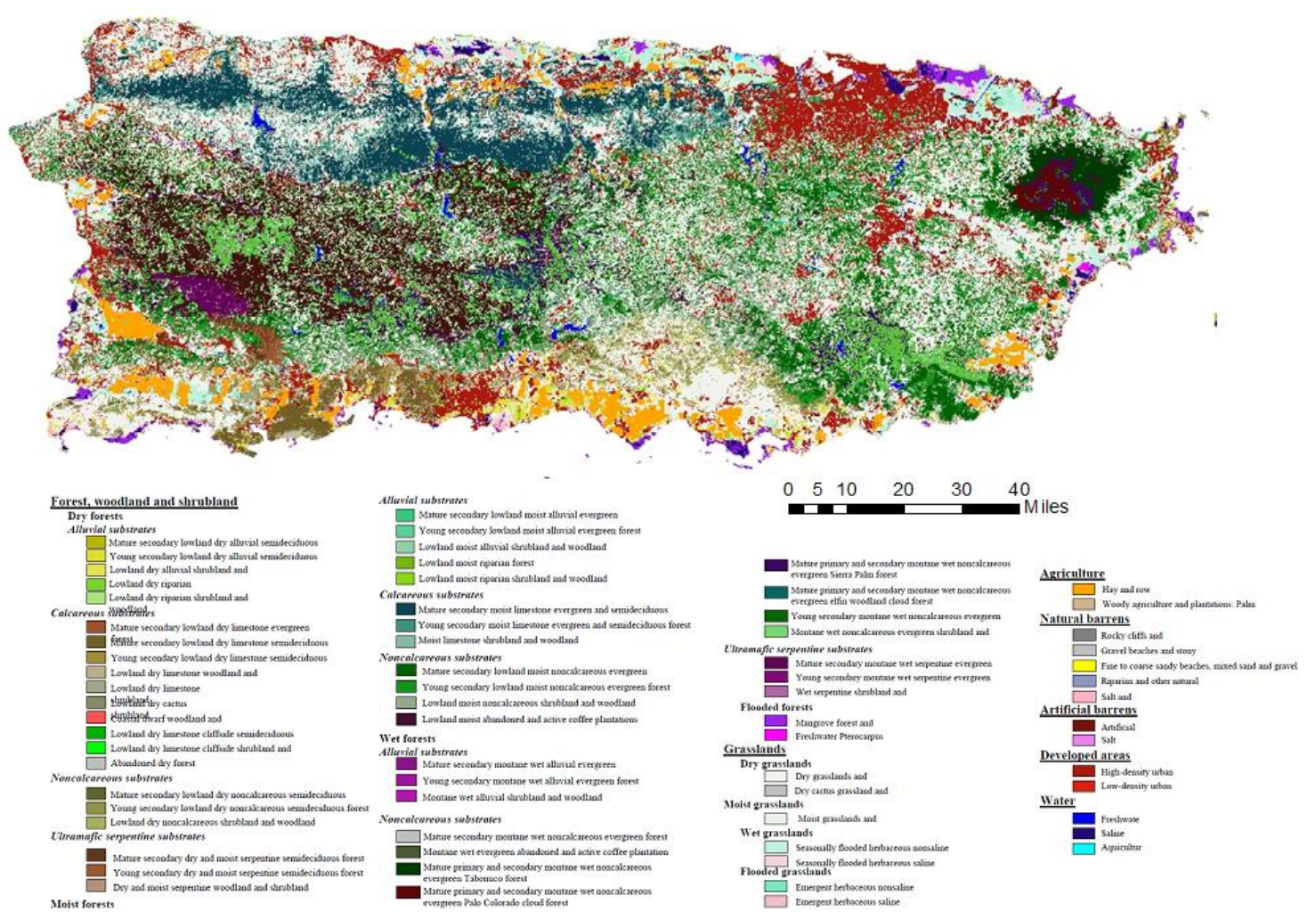

Table 3. Number of stations by Selection Type and Analyzed HELZ and Land Cover for the 1992 Puerto Rico Land Cover Map.

\begin{tabular}{|c|c|c|c|c|c|c|c|c|c|c|}
\hline \multicolumn{11}{|c|}{1992 Puerto Rico Land Cover Map Stations by Analyzed Selection Type and Study Regions } \\
\hline \multirow[t]{2}{*}{ HELZ } & \multirow{2}{*}{$\begin{array}{c}\text { Total } \\
\text { Stations }\end{array}$} & \multirow{2}{*}{$\begin{array}{c}\text { HELZ } \\
\text { Subdivisions }\end{array}$} & \multicolumn{2}{|c|}{ Selection A } & \multicolumn{2}{|c|}{$\begin{array}{c}\text { Selection B } \\
30 \mathrm{~m} \\
\end{array}$} & \multicolumn{2}{|c|}{$\begin{array}{c}\text { Selection B } \\
60 \mathrm{~m}\end{array}$} & \multicolumn{2}{|c|}{$\begin{array}{c}\text { Selection B } \\
\quad 90 \mathrm{~m} \\
\end{array}$} \\
\hline & & & $\mathbf{U}$ & NU & $\mathbf{U}$ & $\mathbf{U}$ & NU & NU & NU & NU \\
\hline \multirow{3}{*}{ Wet Forest } & \multirow{3}{*}{27} & Regenerated & 0 & 22 & 0 & 22 & 4 & 18 & 7 & 15 \\
\hline & & Unregenerated & 0 & 3 & 0 & 3 & 0 & 3 & 0 & 3 \\
\hline & & Rain Forest Reserve & 0 & 2 & 0 & 2 & 0 & 2 & 0 & 2 \\
\hline $\begin{array}{l}\text { Moist } \\
\text { Forest }\end{array}$ & 75 & N/A & 13 & 62 & 21 & 54 & N/A & N/A & N/A & N/A \\
\hline Dry Forest & 24 & N/A & 2 & 22 & 4 & 20 & 11 & 13 & N/A & N/A \\
\hline
\end{tabular}

Each selection data set was evaluated in an independent replicated analysis. 
Table 4. Number of stations by Selection Type and Analyzed HELZ and Land Cover for the 2004 Puerto Rico Gap Map.

\begin{tabular}{ccccccccc}
\hline \multicolumn{2}{c}{2004 Puerto Rico GAP Map \# of Stations by Analyzed Selection Type and Study Regions } \\
\hline \multirow{2}{*}{ HELZ } & Total & \multirow{2}{*}{\begin{tabular}{c} 
HELZ Subdivisions \\
\cline { 3 - 8 }
\end{tabular}} & Stations & Selection A & Selection B 30 m & Selection B 60 m \\
\cline { 3 - 8 } & & Regenerated & 0 & 22 & 0 & 22 & 0 & 22 \\
\multirow{2}{*}{ Wet Forest } & \multirow{2}{*}{27} & Unregenerated & 0 & 3 & 0 & 3 & 0 & 3 \\
& & Rain Forest Reserve & 0 & 2 & 0 & 2 & 0 & 2 \\
Moist Forest & 75 & N/A & 7 & 68 & 11 & 64 & 15 & 60 \\
Dry Forest & 24 & N/A & 3 & 21 & 4 & 20 & 5 & 19 \\
\hline
\end{tabular}

Each selection data set was evaluated in an independent replicated analysis.

Monthly total average, median and average total precipitation for each year were computed directly from the monthly data to statistically evaluate decadal, monthly and seasonal differences. The summarized data were computed by averaging all stations inside the HELZs, the subdivided HELZs and the urban areas from the 1992 and 2004 LULC maps. The averages represent total averages for each month, and the medians represent the median of the median values for total precipitation for each month respectively throughout the 1900-2007 period. Monthly summary data were computed by averaging or identifying the median precipitation values for each month for the period 1900 to 2007 for each region. Seasonal precipitation was computed by averaging monthly totals corresponding to the local Dry Season from December to April and the Wet Season from May to November [24]. Finally, ARC MAP 10.1 IDW interpolation tool was used to create precipitation maps for each period to later extract and assess urban vs. non-urban magnitudes with statistical methods.

\section{Results and Discussion}

In Puerto Rico there are two statistically distinctive $(\alpha=0.05)$, periods of rainfall: the Dry Season or Winter (December to April) and the Wet Season or Summer (May to November). Wet months and wet places show higher rainfall variation while dry months and drier places show less rainfall variation (Figure 6). Median and average annual cycle curves tend to separate late in the wet season as a result of larger rainfall events at the end of the summer months. During the annual cycle a small variation at urban stations seem to occur as they receive less rainfall during the Wet Season and in general slightly more precipitation falls in the non-urban region, in particular this is true for the Wet Forest and Moist Forest HELZs, however the Dry Forest showed a different pattern in some selection method samples by registering more precipitation in urban stations than in non-urban. (Figures 7-13).

Historical monthly cycle graphs show the highest rainfall variability occurs either at the beginning of the Wet Season or at during driest months (June and July) where most of the precipitation deficits are evident in all HELZs and across climatological periods (Figures 14-17). The peak months of the Wet Season are more consistent showing the least variability over time. Wet Season Precipitation has been decreasing in all HELZ through the century while Dry Season precipitation showed slight increases in the Moist Forest and Dry Forest, but the Dry Forest have been the HELZ with the highest and most notable increase (Figure 18). 
Figure 6. Average and median monthly precipitation for urban stations by HELZ.

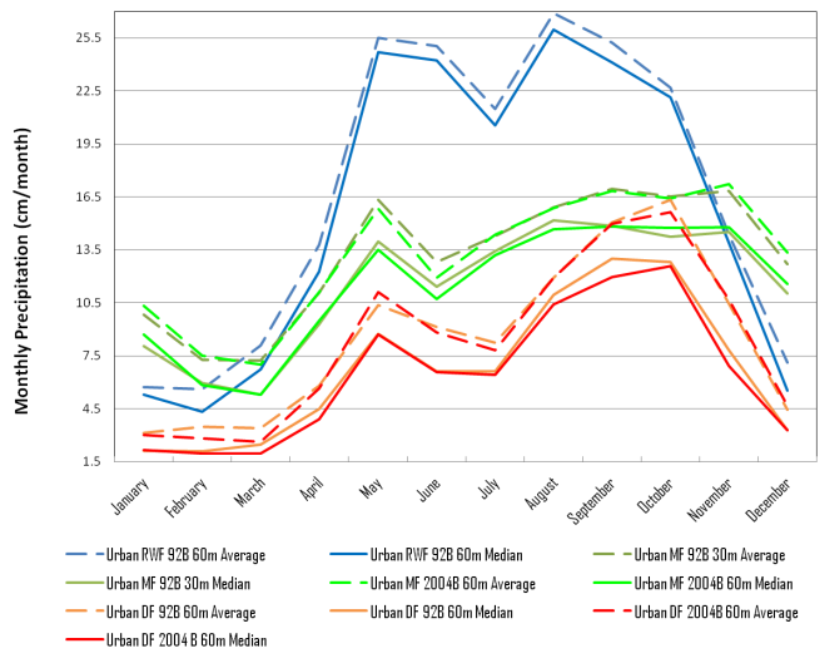

Figure 7. Average and median urban and non-urban monthly precipitation, Wet Forest.

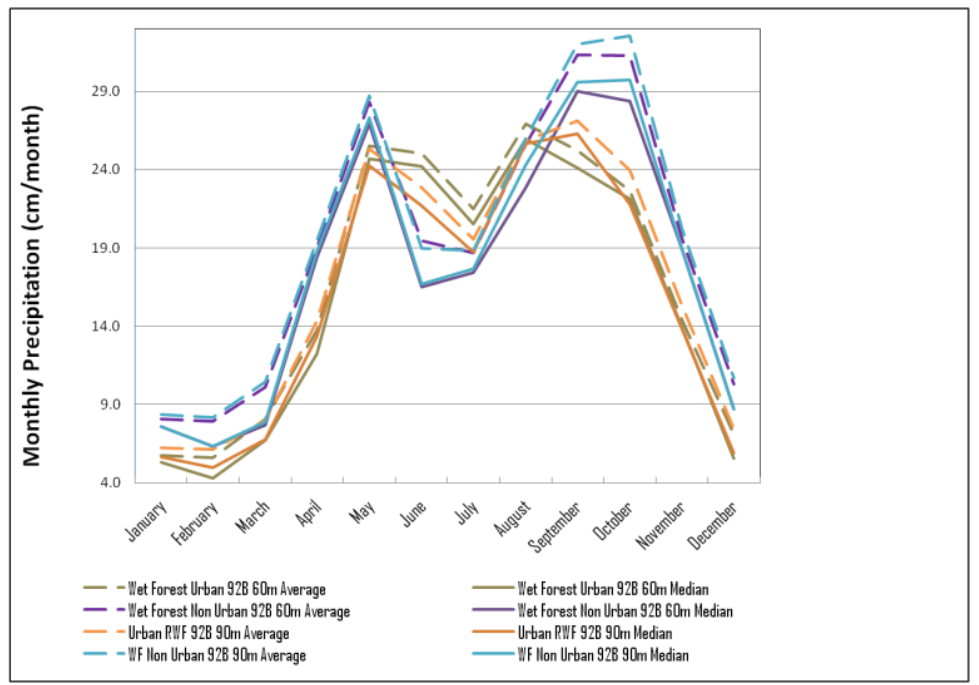

Figure 8. Monthly average and median precipitation for the moist forest urban $\mathrm{A}$ and non-urban.

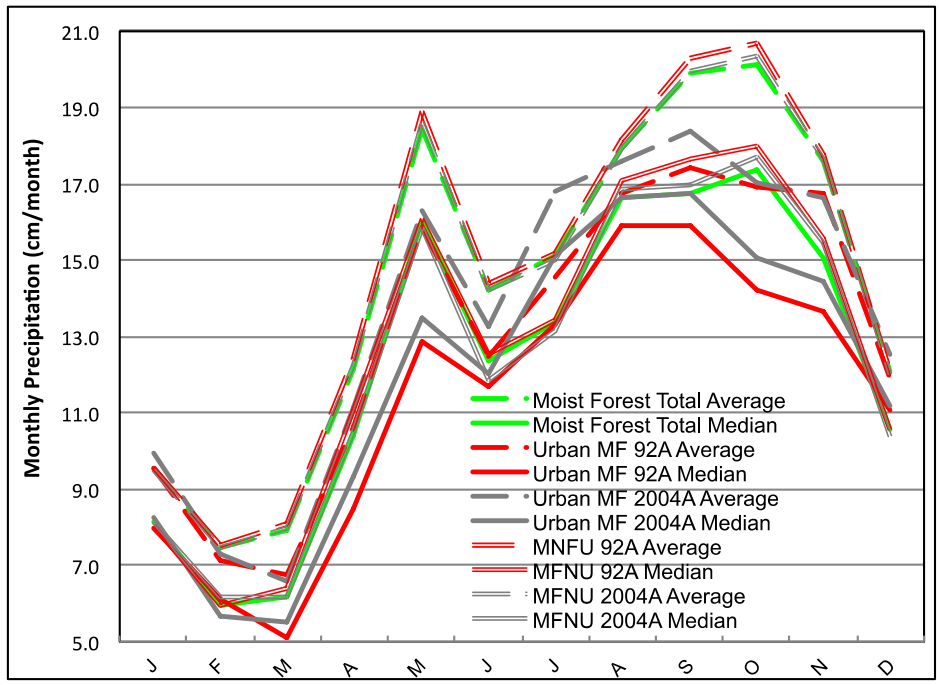


Figure 9. Monthly average and median precipitation for the moist forest urban B and non-urban.

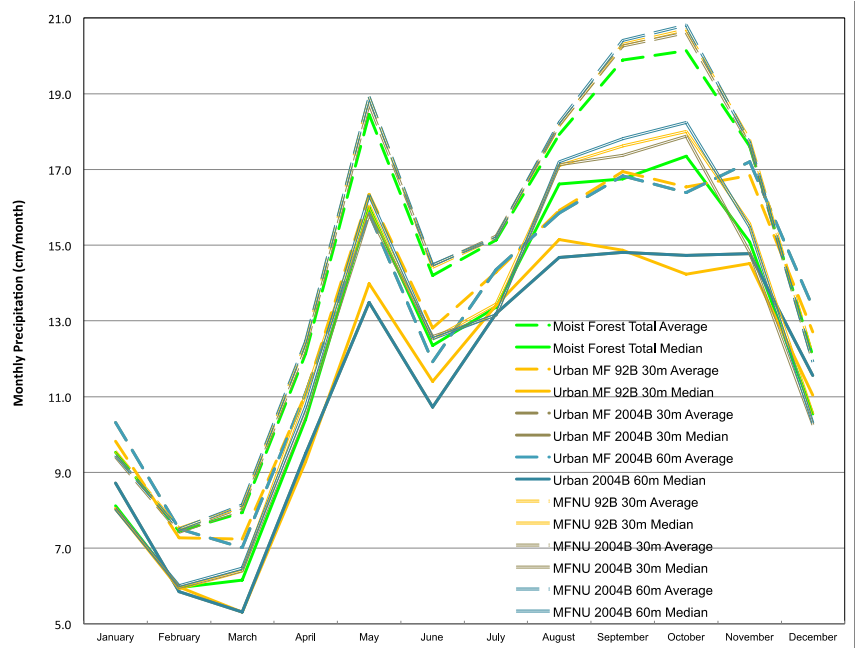

Figure 10. Average monthly precipitation for the dry forest urban 1992 A and non-urban.

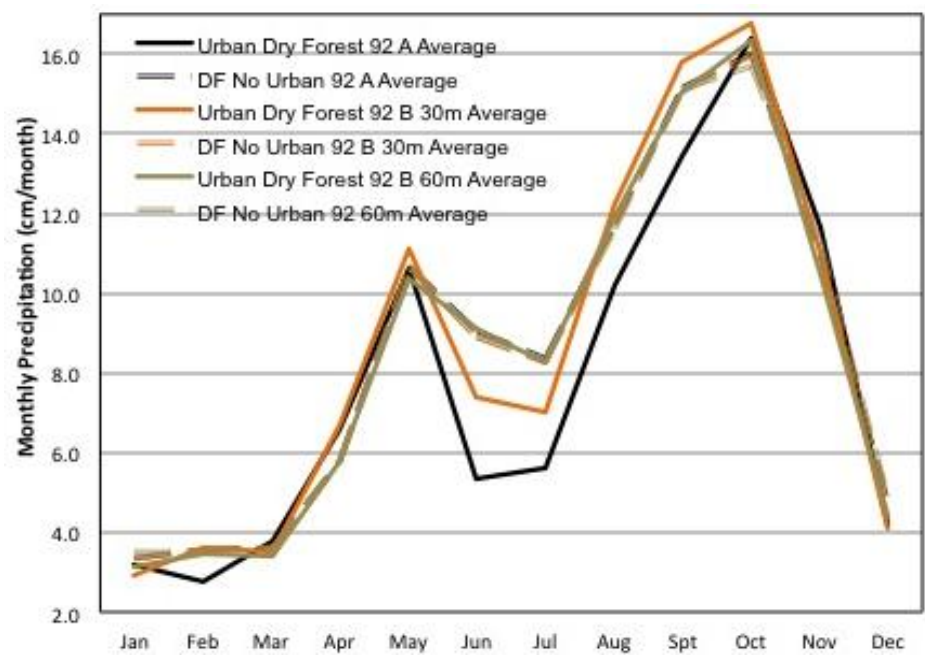

Figure 11. Median monthly precipitation for the dry forest urban 1992 A and non-urban.

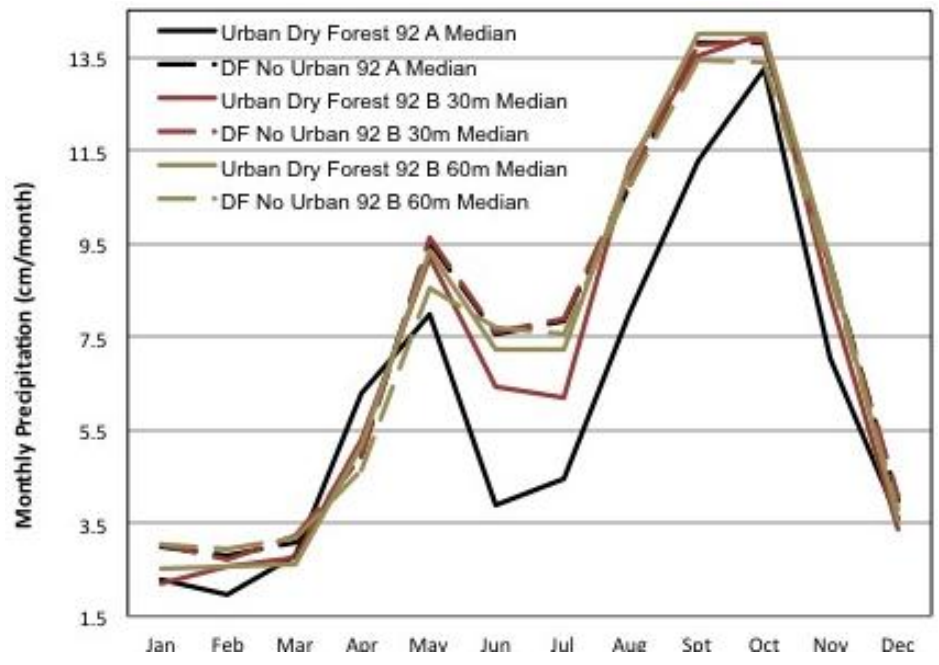


Figure 12. Average monthly precipitation for dry forest 2004 urban and non-urban.

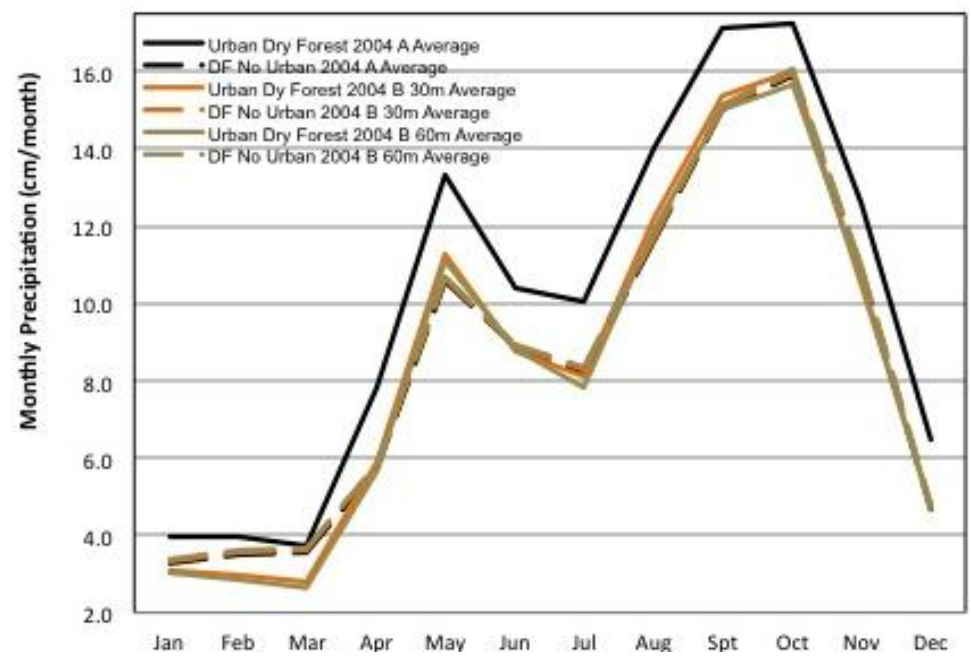

Figure 13. Median monthly precipitation for dry forest 2004 urban vs. non-urban.

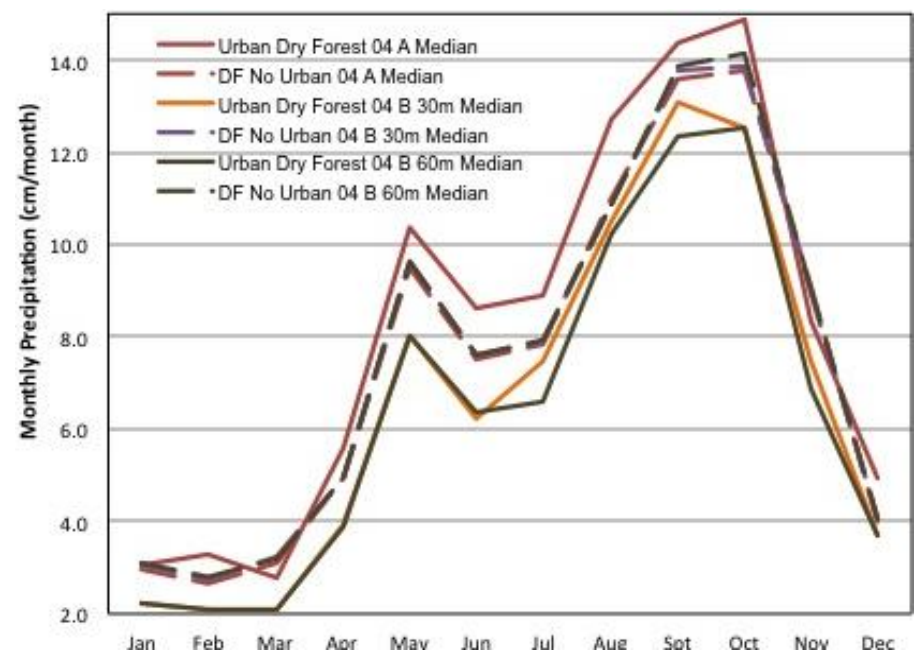

Figure 14. Puerto Rico annual cycle monthly precipitation by period.

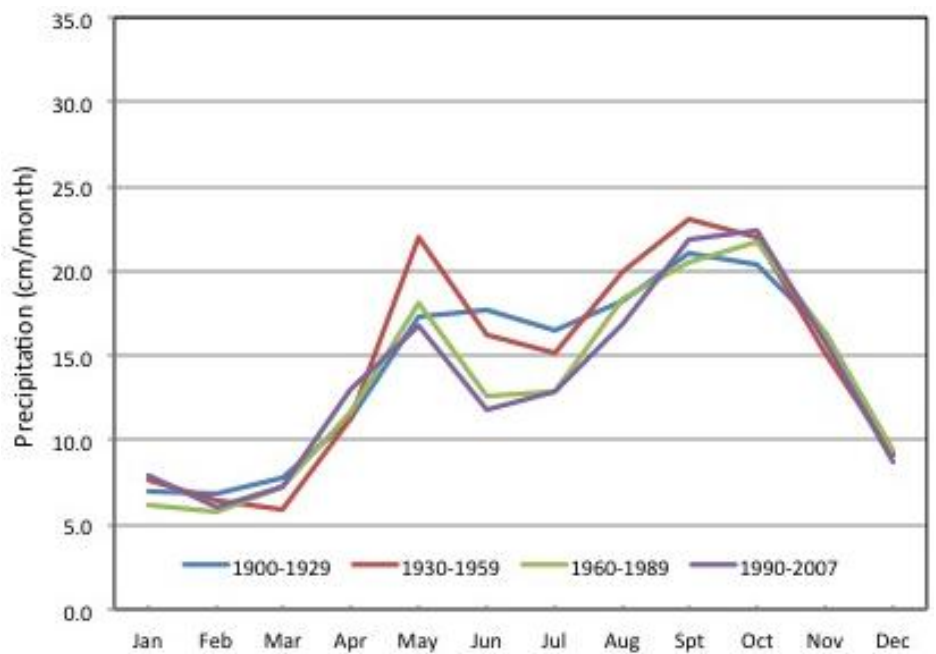


Figure 15. Wet forest annual cycle monthly precipitation by period.

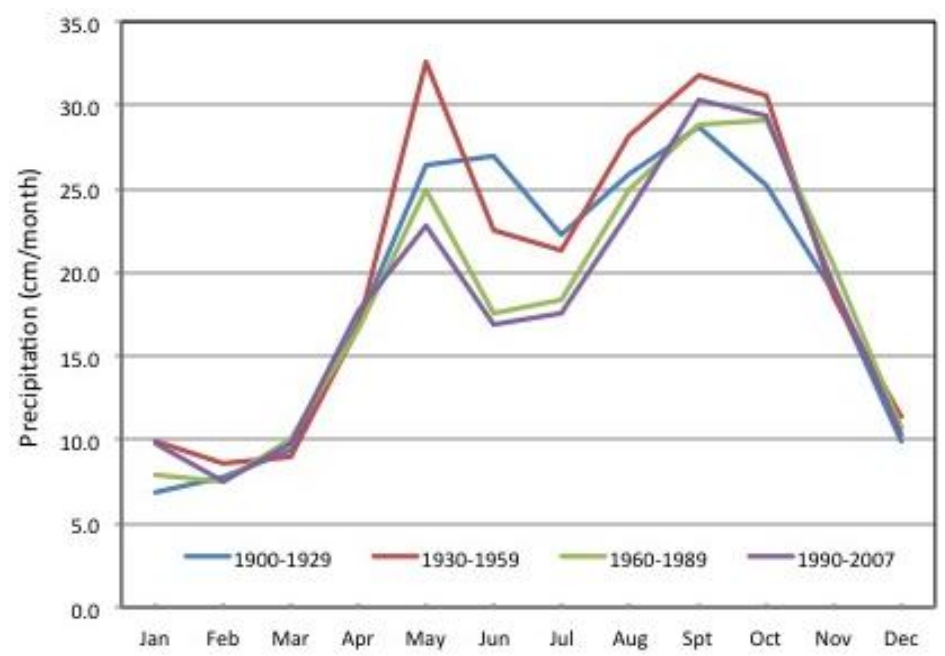

Figure 16. Moist forest annual cycle monthly precipitation by period.

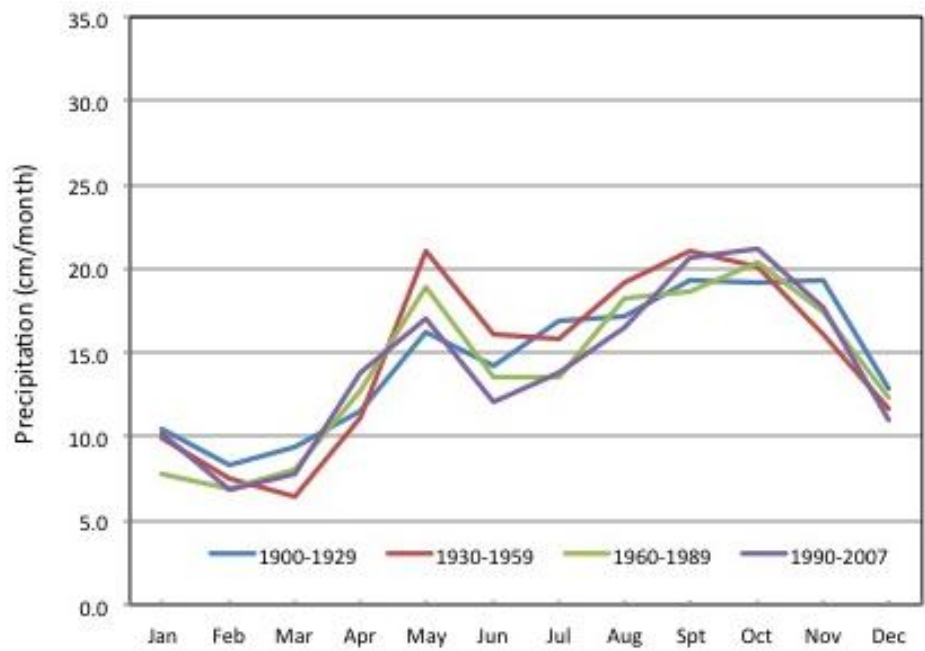

Figure 17. Dry forest annual cycle monthly precipitation by period.

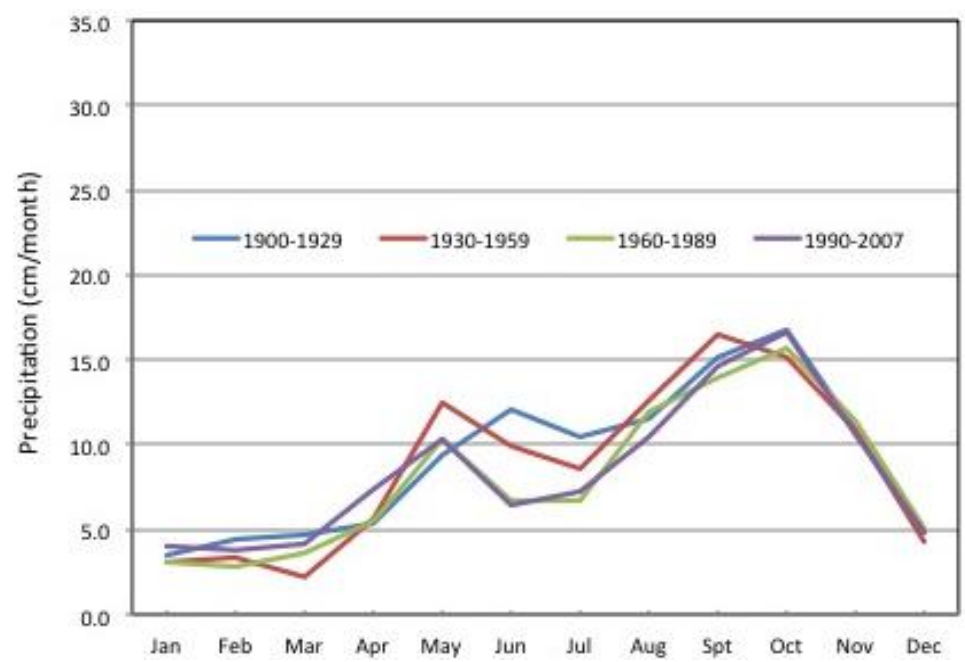


Historical trends for the 90th, 50th, and 10th percentiles of monthly precipitation for the 30-year climatological periods in each HELZ have decreased (Figures 19-21). Most of the trends decrease for the entire century however, the 90th percentile in the Wet Forest and the Dry Forest have an increasing trend, suggesting an increase in frequency of larger precipitation periods (months or years) in these two HELZs while smaller periods are decreasing across the entire island. Despite the dominant decreasing trend in the 50th percentile, this parameter has been increasing since 1989 in all HELZ indicating an increase in median precipitation in the last 17 years. All 10th percentiles have been decreasing rapidly for the entire century in each HELZ, indicating a strong decrease in small precipitation periods, however only in the Dry Forest has the 10th percentile been increasing in the last 17 years. The decrease in precipitation combined with an increase of heavy precipitation periods in the most recent 17 years matches projections for the Caribbean Basin under climate change scenarios [14]. Although from the data analyzed the magnitude and intensity of precipitation events is not evident, periods of larger precipitation may occur by either low frequency of large precipitation events or high frequency of small precipitation events both yielding large amounts of total accumulations for a given period (months or years). Climate change projections for the Caribbean point at higher frequency of dry periods combined with a lower frequency of high precipitation periods [14].

Figure 18. Seasonal monthly total precipitation by period.

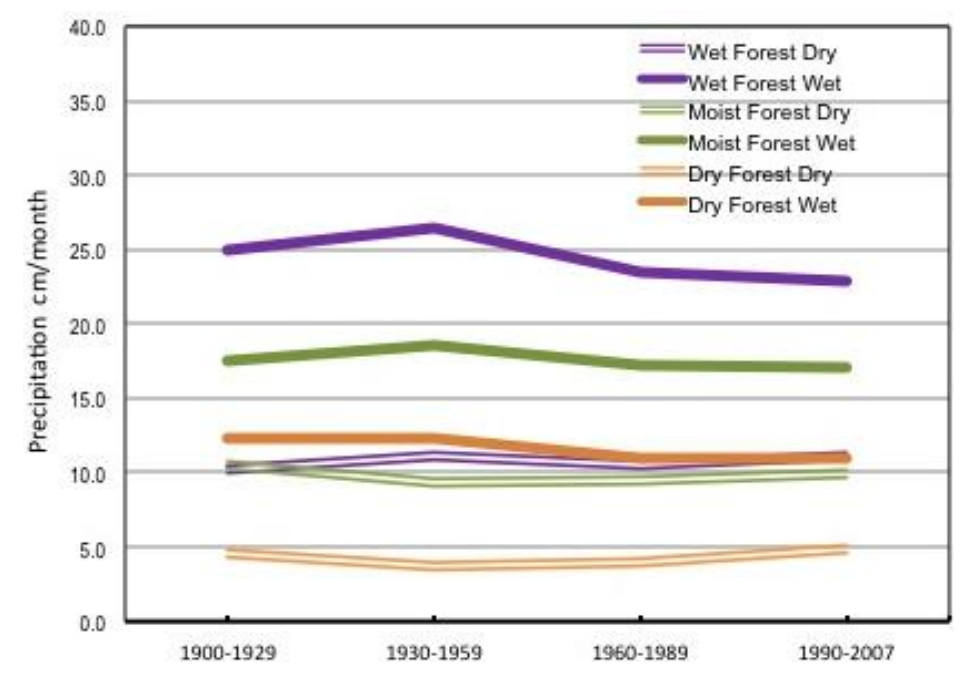

Monthly precipitation for the period 1900-2007 in most areas of Puerto Rico follows a Gaussian (Normal) distribution. However, eastern HELZ Subdivision sites precipitation record fitted the Johnson transformation distribution (Table 5), which may suggest a different dominant synoptic or sea breeze orographic forcing rainfall origin at these locations. At all Wet Forest Subdivisions median precipitation is higher than the average (Table 5) as they receive more rain events of higher magnitudes than other HELZ's. Of the three HELZ studied, the most precipitation falls in the Wet Forest, as expected, followed by the Moist Forest while the Dry Forest receives the lowest precipitation and is statistically different from the Moist Forest and the Wet Forest $(\alpha=0.05)$. The Moist Forest and the Wet Forest precipitation average are higher than the average precipitation for the main three HELZs. 
Average annual precipitation in Puerto Rico has been decreasing for the past century (1900-1990) in all three HELZs with most stations recording negative trends (Figure 3). However, in particular stations, zones and time periods, positive trends have also occurred (Figures 21 and 22). Since the 1970s average annual precipitation level has increased (Figure 3). A notable increase in median precipitation primarily in the Wet Forest from 1920s to the 1950s was followed by a dramatic drop in median precipitation in all HELZs after 1970, but all HELZs show increasing median and average precipitation in the last decade of the record (Figure 3). Dry and wet periods in Puerto Rico seem to follow a cyclic pattern consistent in the Caribbean basin that has been associated with the North Atlantic Oscillation [31]. Average and median decadal precipitation has greater separation since the 1970s, particularly in the Dry Forest (Figure 3). Average and median rainfall has increased consistently in the Dry Forest since the 1970s while in the Moist and Wet Forests it began since the 1990s (Figure 3). Greater separation between average and median curves after 1970 is consistent with global warming projections for the Caribbean of an increase in drier periods combined with larger precipitation events [14].

Figure 19. Annual precipitation quantiles for wet forest by period.

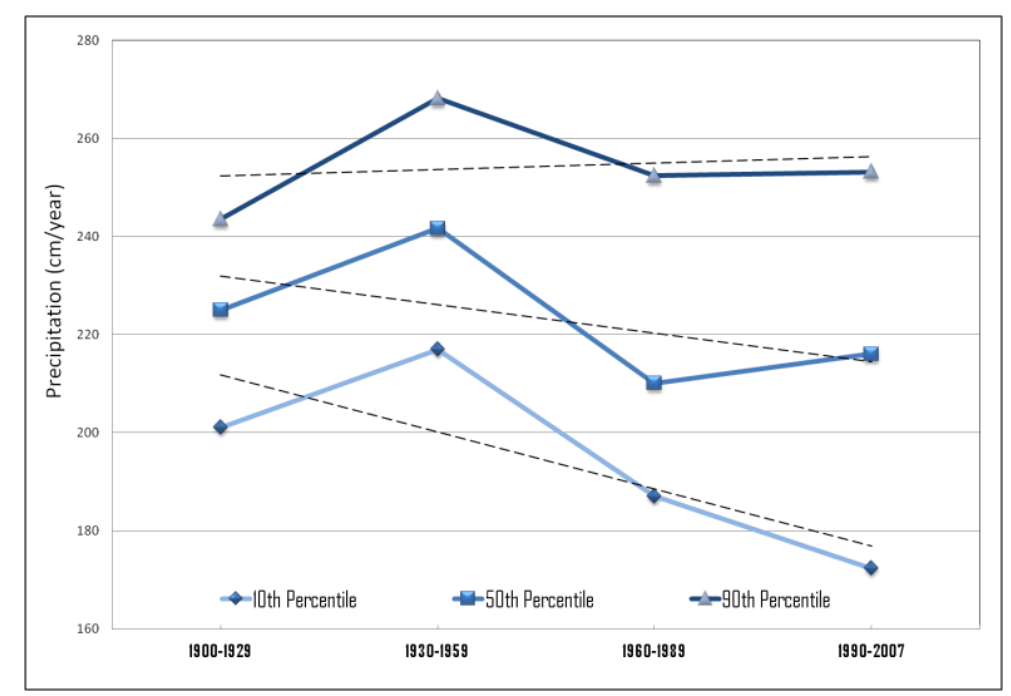

Figure 20. Annual precipitation quantiles for moist forest by period.

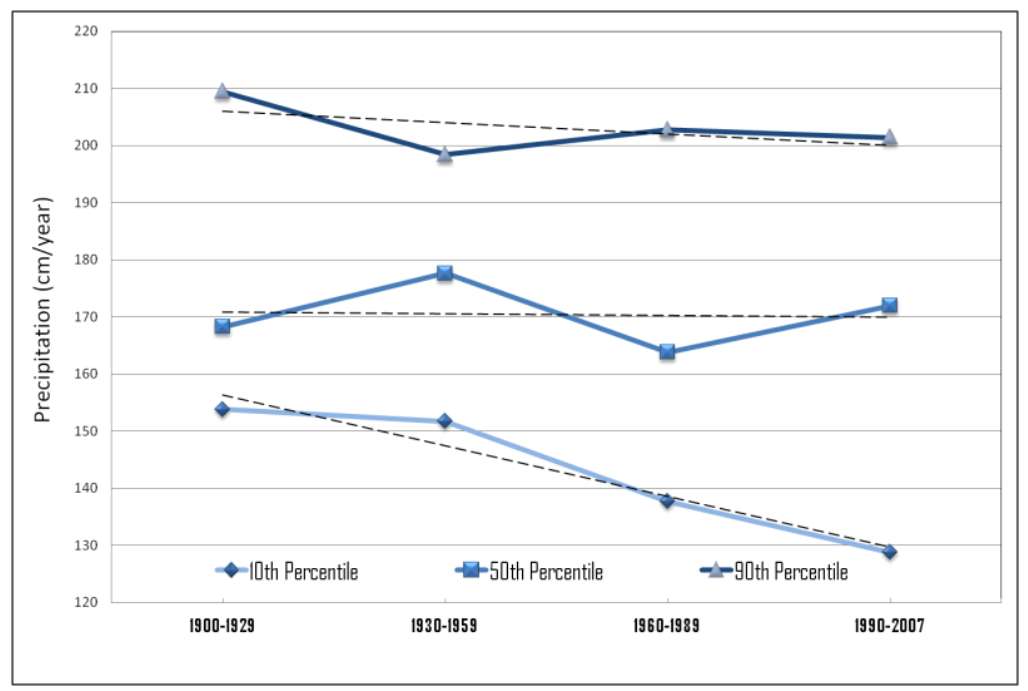


Figure 21. Annual precipitation quantiles for dry forest by period.

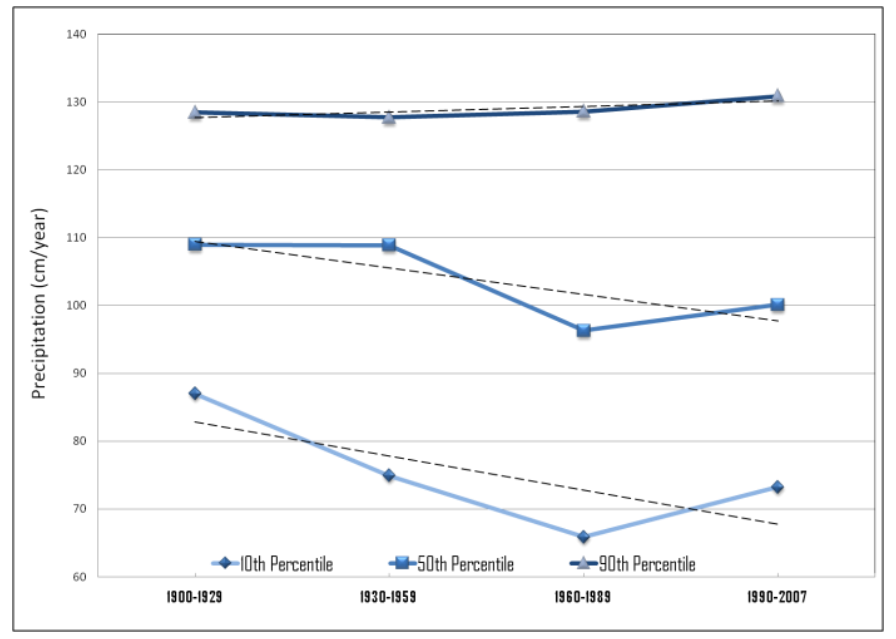

Table 5. Holdridge ecological life zones distributions and descriptive statistics.

\begin{tabular}{|c|c|c|c|c|c|c|}
\hline HELZ & Data Distribution & $\begin{array}{c}\text { Mean } \\
\text { (cm/month) }\end{array}$ & $\begin{array}{l}\text { Standard } \\
\text { Deviation }\end{array}$ & $\begin{array}{c}\text { Median } \\
\text { (cm/month) }\end{array}$ & $\begin{array}{c}\text { Maximum } \\
\text { (cm/month) }\end{array}$ & Remarks \\
\hline WFR & $\begin{array}{c}\text { Johnson } \\
\text { Transformation }\end{array}$ & 21.89 & 6.198 & 24.95 & 29.12 & $\begin{array}{l}\text { Rain Forest Reservation. Wettest } \\
\text { region in Puerto Rico, different to most } \\
\text { of Puerto Rico. Median above Average }\end{array}$ \\
\hline WF & Gaussian & 18.29 & 8.165 & 17.76 & 30.27 & $\begin{array}{l}\text { Center Mountains. Highest rainfall } \\
\text { variation and maximum }\end{array}$ \\
\hline UnWF & $\begin{array}{c}\text { Johnson } \\
\text { Transformation }\end{array}$ & 19.79 & 6.733 & 23.10 & 27.32 & $\begin{array}{l}\text { Eastern Mountain, Median } \\
\text { above Average }\end{array}$ \\
\hline RWF & Gaussian & 18.52 & 8.484 & 18.88 & 30.19 & $\begin{array}{l}\text { Regenerated Wet Forest, Median } \\
\text { Above Average }\end{array}$ \\
\hline MF & Gaussian & 14.20 & 4.773 & 14.34 & 20.18 & $\begin{array}{l}\text { Most of Puerto Rico. Mean and } \\
\text { median very similar }\end{array}$ \\
\hline DF & Gaussian & 8.19 & 4.447 & 7.80 & 15.33 & $\begin{array}{l}\text { Driest region in Puerto Rico. } \\
\text { Significantly different to ALL others } \\
\text { in every test }\end{array}$ \\
\hline
\end{tabular}

Figure 22. 1900-2007 precipitation trends by station.

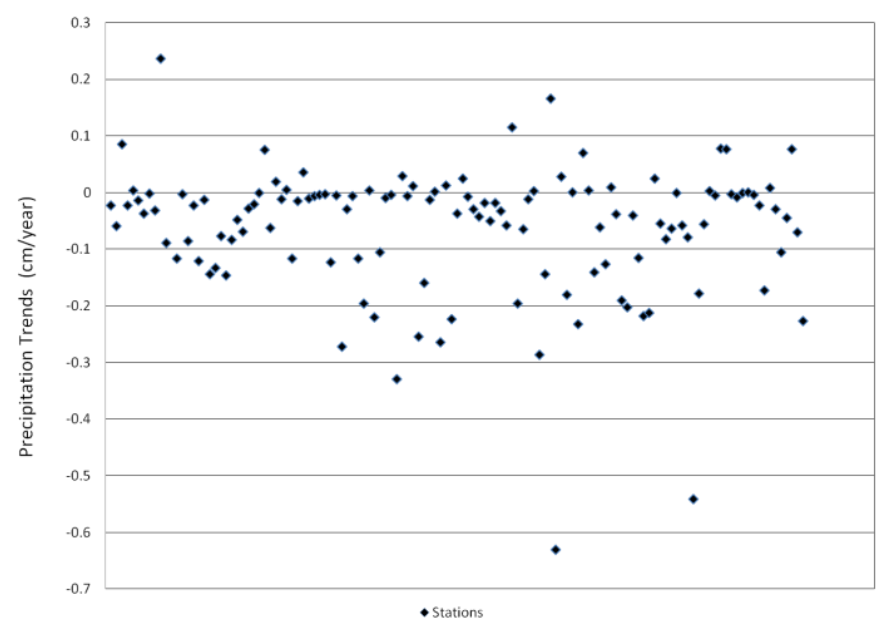


Table 6. 1992 land use and land cover (LULC) average monthly precipitation ratio 1900-2007.

\begin{tabular}{|c|c|c|c|c|c|c|c|c|c|}
\hline \multirow{2}{*}{1992} & \multirow{2}{*}{$\begin{array}{c}\text { Total } \\
\text { cm/month }\end{array}$} & \multirow{2}{*}{$\begin{array}{l}\text { HELZ/PR } \\
\mathrm{cm} / \mathrm{month}\end{array}$} & \multicolumn{2}{|c|}{ Selection A } & \multicolumn{2}{|c|}{ Selection B 30 m } & \multicolumn{2}{|c|}{ Selection B $60 \mathrm{~m}$} & \multirow{2}{*}{ Remarks } \\
\hline & & & Urban & Non Urban & Urban & Non Urban & Urban & Non Urban & \\
\hline WF & 18.29 & 1.32 & N/A & N/A & 1.07 & 0.99 & 0.91 & 1.01 & $\begin{array}{l}\text { Urban B } 30 \text { More precipitation } \\
\text { over urban }\end{array}$ \\
\hline MF & 14.20 & 1.02 & 0.90 & 1.01 & 0.91 & 1.02 & 0.91 & 1.02 & $\begin{array}{l}\text { Less precipitation over urban } \\
\text { areas } v s . \text { no urban }\end{array}$ \\
\hline $\mathrm{DF}$ & 7.80 & 0.56 & 0.97 & 1.06 & 1.02 & 1.06 & 1.02 & 1.08 & $\begin{array}{l}\text { Less precipitation over urban areas } \\
v s . \text { no urban. Smaller difference }\end{array}$ \\
\hline PR & 13.88 & 1.00 & 0.87 & 1.02 & 0.89 & 1.00 & 0.85 & 1.03 & $\begin{array}{l}\text { Less precipitation over urban } \\
\text { areas } v s . \text { no urban }\end{array}$ \\
\hline
\end{tabular}

In general, urban areas received slighter less average precipitation than the non-urban areas in each HELZ, with the exception of the 1992 map B selection 30-meter buffer. Table 6 shows urban vs. non-urban average monthly precipitation differences expressed using a ratio in every HELZ and for every selection method. Ratio values $>1$ indicate average monthly precipitation that is above the average for Puerto Rico as a whole or the HELZ, values < 1 indicate the contrary. The 2004 map station selections consistently showed more rainfall over urban areas than over non-urban in the Dry Forest in all selections (Table 7).

Table 7. 2004 LULC average monthly precipitation ratio 1900-2007.

\begin{tabular}{|c|c|c|c|c|c|c|c|c|c|}
\hline \multirow{2}{*}{2004} & \multirow{2}{*}{$\begin{array}{c}\text { Total } \\
\text { cm/month }\end{array}$} & \multirow{2}{*}{$\begin{array}{l}\text { HELZ/PR } \\
\text { cm/month }\end{array}$} & \multicolumn{2}{|c|}{ Selection A } & \multicolumn{2}{|c|}{ Selection B $30 \mathrm{~m}$} & \multicolumn{2}{|c|}{ Selection B $60 \mathrm{~m}$} & \multirow{2}{*}{ Remarks } \\
\hline & & & Urban & Non Urban & Urban & Non Urban & Urban & Non Urban & \\
\hline WF & 18.29 & 1.32 & N/A & N/A & N/A & N/A & N/A & N/A & $\begin{array}{l}\text { Less precipitation over } \\
\text { urban areas } v s . \text { no urban }\end{array}$ \\
\hline MF & 14.20 & 1.02 & 0.96 & 0.99 & 0.94 & 1.00 & 0.95 & 1.00 & $\begin{array}{l}\text { Less precipitation over } \\
\text { urban areas vs. no urban }\end{array}$ \\
\hline DF & 7.80 & 0.56 & 1.26 & 1.02 & 1.17 & 1.03 & 1.08 & 1.05 & $\begin{array}{l}\text { More precipitation over } \\
\text { urban areas } v s . \text { no urban }\end{array}$ \\
\hline PR & 13.88 & 1.00 & 0.901 & 0.910 & 0.882 & 0.914 & 0.877 & 0.917 & $\begin{array}{l}\text { Less precipitation over } \\
\text { urban areas } v s \text {. no urban }\end{array}$ \\
\hline
\end{tabular}

\subsection{ANOVA Results}

Urban regions may induce precipitation because of increased convection and/or convergence over the city and the presence of favorable aerosols for cloud formation. On the other hand precipitation may decrease because of the presence of particular unfavorable aerosols for cloud formation, air pollution, a decrease in the mixing ratio or less available moisture. If urban areas in Puerto Rico are affecting local precipitation then there should be differences between urban and non-urban regions. However, no statistically significant differences were found in average monthly precipitation between urban areas and non-urban areas in each HELZ in any selection type or buffer size based on One Way ANOVA $(\alpha=0.05)$. Thus we reject the null hypothesis that there are significant differences in average monthly precipitation between urban and non-urban areas. In addition, our results are independent of 
the selection method used to categorize stations between urban and non-urban. In other words, urban and non-urban areas receive statistically the same amounts of monthly average precipitation and, based on the data and methods used, the development of urban landscapes has not significantly changed the amounts of rainfall compared to the average and variability of the corresponding HELZ. This result contrasts with effects observed in larger continental cities, and may reflect the overwhelming dominance of maritime or synoptic conditions in controlling precipitation across Puerto Rico, little contrast between urban and non-urban areas or the small size of urban areas in the island. These results are in agreement with results presented by Comarazamy and Gonzalez [40] that suggested that large historical precipitation changes were associated to global and regional-scale climate changes, but little change was found due to historical LUCC

\subsection{Precipitation Trends}

In general, decreasing trends dominate average rainfall over Puerto Rico for the last century regardless of HELZ (Figure 22), which is consistent with reports of decreasing Caribbean precipitation [31]. However, the most recent 17 years show a different pattern, with most stations having positive trends (Figures 23 and 24). In the Dry Forest a different pattern than the other HELZ occurred, with increasing precipitation trends in the urban area for most time periods that were analyzed (century, PRISM, NARR), consistently contradicting the long term pattern of decreasing trends that dominate the island. Thus, even on a small island in the Tropics the scale of Puerto Rico, there are noticeable intraregional climatic differences. HELZs are important to account for when comparing urban and rural climate stations because detectable differences may be because of natural differences in microclimates.

Figure 23. 1900-2007 station precipitation trends by period.

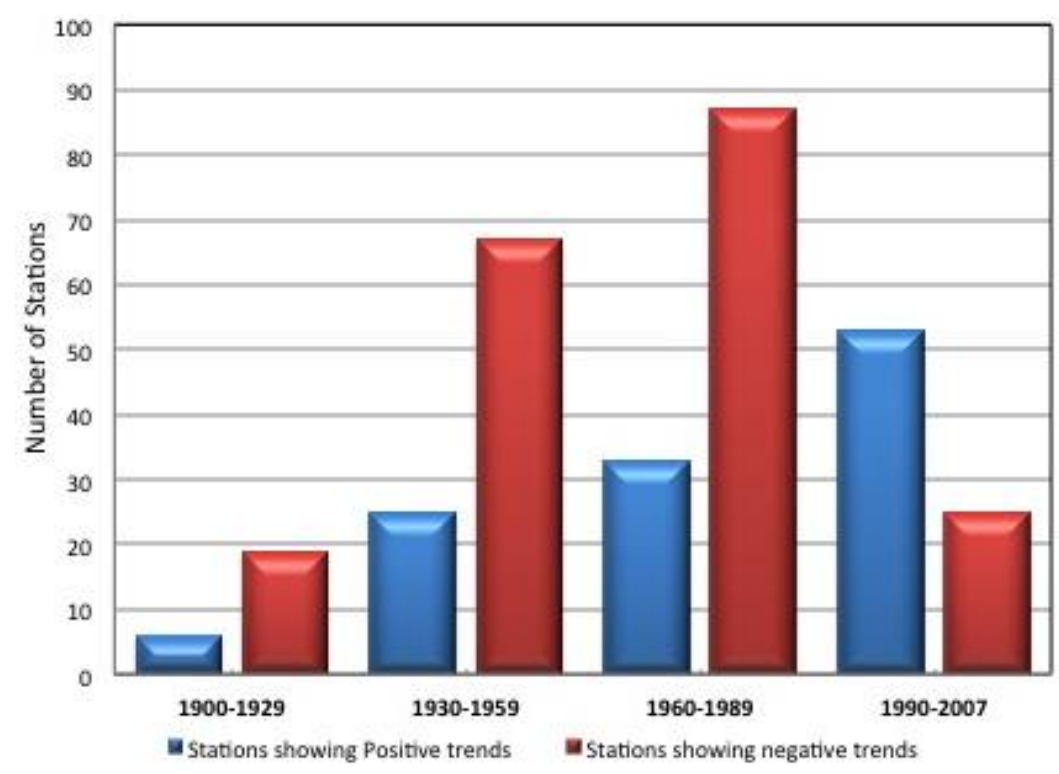


Figure 24. Number of stations with positive vs. negative trends by HELZ and period.

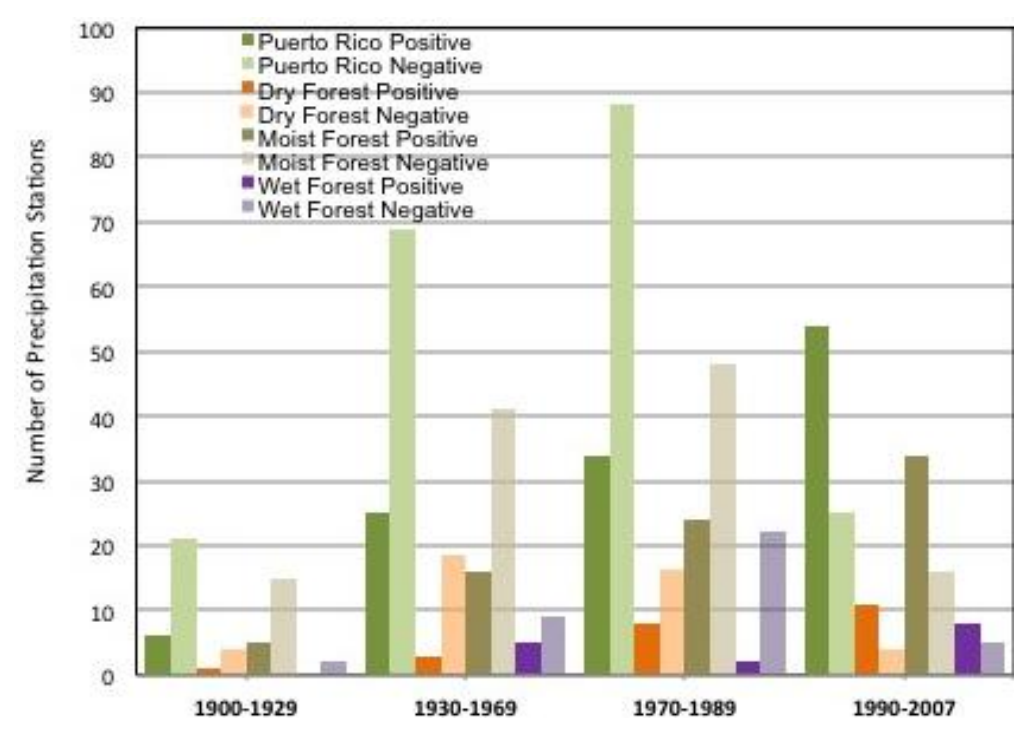

\subsection{GIS Interpolated Maps Analysis}

Yearly average total precipitation and its corresponding trends from surface stations were interpolated with GIS ARC MAP 10.1 to further investigate precipitation patterns and changes related to urban and non-urban areas at each HELZ. The data were divided into the study periods previously mentioned and average values were interpolated applying the IDW method commonly used for precipitation point data. Statistical analysis was performed on GIS generated grid cells to evaluate urban $v s$. non-urban magnitudes.

We found statistical differences between urban and non-urban yearly average total precipitation in most time periods and HELZs (Tables 8 and 9). These findings were consistent with GIS analysis of PRISM maps generation by a different method not considering any land covers, using different spatial resolution and time period. However, some findings were counter-intuitive as there is no clear correlation between urban and non-urban precipitation with direction, time, quantity and location (Figures 25 and 26). We expected that any urban impacts on precipitation would be evident or limited to the later periods when urban development and buildup has been notably intense. Statistical differences between urban and non urban areas from the beginning of the century would suggest that urban impacts have always existed locally or that rainfall naturally splits statistically differently at urban and non urban locations. 
Table 8. Yearly Average Total Precipitation for each period and its corresponding Urban vs. Non urban T-test significance values: $270 \mathrm{~m}$ grid size.

\begin{tabular}{|c|c|c|c|c|c|c|c|c|c|c|c|c|c|c|c|c|c|c|c|c|c|}
\hline & \multicolumn{3}{|c|}{$1900-1929 \mathrm{~cm} /$ year } & \multicolumn{3}{|c|}{ 1930-1959 cm/year } & \multicolumn{3}{|c|}{$1960-1989 \mathrm{~cm} /$ year } & \multicolumn{3}{|c|}{ 1990-2007 cm/year } & \multicolumn{3}{|c|}{$1963-1995 \mathrm{~cm} /$ year } & \multicolumn{3}{|c|}{$1979-2005 \mathrm{~cm} /$ year } & \multicolumn{3}{|c|}{ PRISM cm/year } \\
\hline & $\mathbf{U}$ & & & $\mathbf{U}$ & & Sig. & $\mathbf{U}$ & & Sig. & $\mathbf{U}$ & & & 0 & & Sig. & 0 & NU & Sig. & 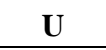 & 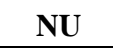 & ig. \\
\hline W & 375.16 & 341.81 & & 29.40 & 98.76 & 000 & 70.76 & 406.70 & & 02.75 & 214.86 & & 04.77 & 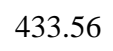 & & 61.72 & 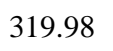 & & -1 & 84 & \\
\hline MF & 347.26 & 340.77 & 0.000 & 79.59 & 338.75 & 000 & 364.01 & 362.77 & 0.027 & 70.64 & 3.18 & 0 & 386.65 & 55 & 7 & 297.06 & 299.43 & & .45 & & 0.000 \\
\hline DF & 26.24 & 220.29 & .000 & 66.67 & 40.35 & .000 & 44.45 & 255.27 & 0.000 & 51.52 & 153.16 & 0.001 & 267.08 & 273.51 & 0.000 & 232.89 & 233.05 & 0.802 & 207.74 & 216.95 & 0.000 \\
\hline
\end{tabular}

Table 9. Yearly average total precipitation for each period and its corresponding urban vs. non urban T-test significance values: $100 \mathrm{~m}$ grid size.

\begin{tabular}{|c|c|c|c|c|c|c|c|c|c|c|c|c|c|c|c|c|c|c|c|c|c|}
\hline & \multicolumn{3}{|c|}{$1900-1929 \mathrm{~cm} /$ year } & \multicolumn{3}{|c|}{$1930-1959 \mathrm{~cm} /$ year } & \multicolumn{3}{|c|}{$1960-1989 \mathrm{~cm} /$ year } & \multicolumn{3}{|c|}{$1990-2007 \mathrm{~cm} /$ year } & \multicolumn{3}{|c|}{$1963-1995 \mathrm{~cm} /$ year } & \multicolumn{3}{|c|}{$1979-2005 \mathrm{~cm} /$ year } & \multicolumn{3}{|c|}{ PRISM cm/year } \\
\hline & $\mathbf{U}$ & NU & Sig. & $\mathbf{U}$ & NU & Sig. & $\mathbf{U}$ & NU & Sig. & $\mathbf{U}$ & NU & Sig. & $\mathbf{U}$ & NU & Sig. & $\mathbf{U}$ & NU & Sig. & $\mathbf{U}$ & NU & Sig. \\
\hline WF & 375.3 & 342.11 & 00 & 4 & 3 & 0 & 0 & 2 & 0 & 1 & 2 & 0.000 & 57 & 07 & 0 & 57 & 32 & 0.000 & 62 & 84 & 000 \\
\hline MF & 347.45 & 341.00 & 0.000 & 260.05 & 341.21 & 0.000 & 364.02 & 362.77 & 0.000 & 169.90 & 183.31 & 0.000 & 387.81 & 385.43 & 0.000 & 298.75 & 299.43 & 0.000 & 99.45 & 104.12 & 0.000 \\
\hline DF & 225.54 & 219.91 & 0.000 & 271.75 & 238.65 & 0.000 & 240.31 & 255.44 & 0.000 & 149.74 & 153.06 & 0.000 & 263.21 & 273.52 & 0.000 & 229.67 & 233.04 & 0.000 & 207.74 & 216.95 & 0.000 \\
\hline
\end{tabular}


Figure 25. Yearly average total precipitation urban $v s$. non-urban difference.

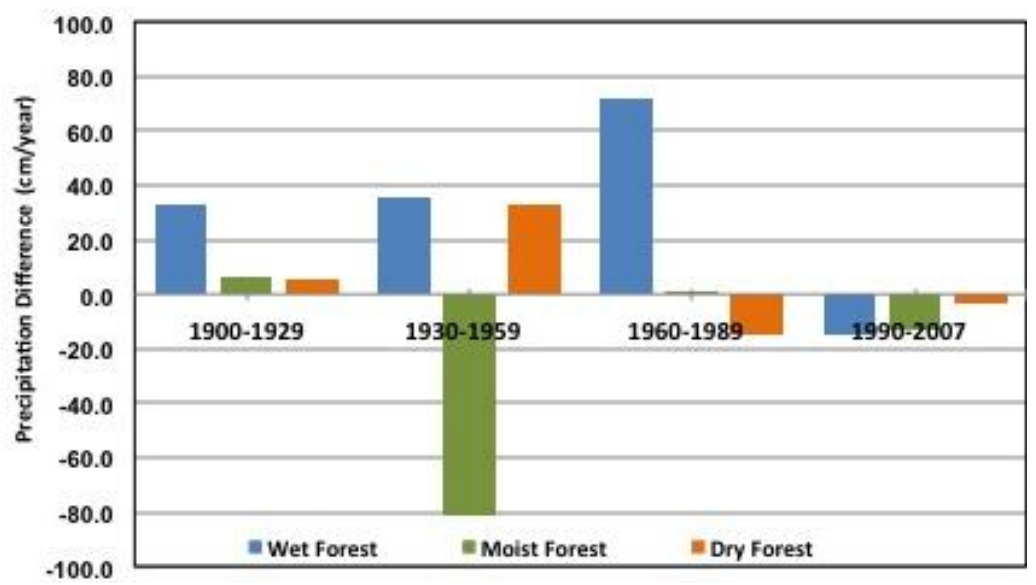

Figure 26. Number of study periods receiving higher yearly average urban vs. non-urban total precipitation.

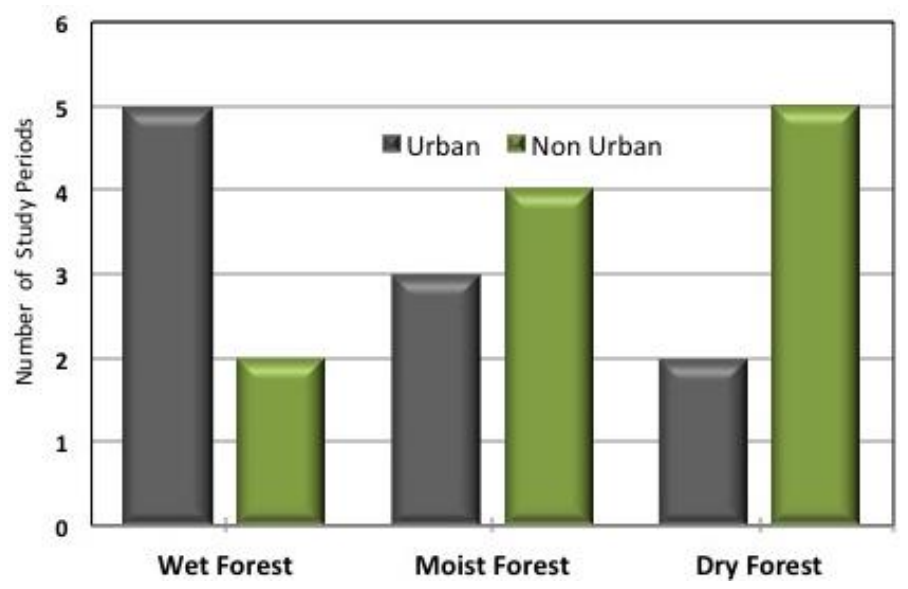

We also found statistical differences between urban $v s$. non-urban yearly average total precipitation trends but this relationship does not remain constant across periods and occurs in both directions in all HELZs (Tables 10 and 11). Higher urban trends prevail in most periods in the Wet Forest and Moist Forest HELZs (Figure 27). Higher urban trends in the Wet Forest had a direct relationship consistent with this HELZ receiving more average total rain than its non urban counterpart as earlier discussed and may indicate the higher sensibility of this HELZ to urban development. Meanwhile the dominance of higher urban trends in the Moist Forest contrasts urban vs. non-urban average totals findings that showed more even split across study periods (Figures 26 and 27). The Dry Forest also contrasts average totals findings by showing a more even urban $v s$. non-urban trends split in the opposite case (Figures 26 and 27). The relationships found in the Moist Forest and Dry Forest urban and non-urban trends by periods, may be indicative of a future shift related to urban development in both regions as they are the two most urbanized HELZs in the island. 
Table 10. The $270 \mathrm{~m}$ grid cell yearly average total precipitation trends for each period and its corresponding urban $v s$. non urban $\mathrm{T}$ test significance values.

\begin{tabular}{|c|c|c|c|c|c|c|c|c|c|c|c|c|c|c|c|c|c|c|c|c|c|}
\hline & \multicolumn{3}{|c|}{$1900-1929 \mathrm{~cm} / \mathrm{year}$} & \multicolumn{3}{|c|}{$1930-1959 \mathrm{~cm} /$ year } & \multicolumn{3}{|c|}{$1960-1989 \mathrm{~cm} /$ year } & \multicolumn{3}{|c|}{$1990-2007 \mathrm{~cm} /$ year } & \multicolumn{3}{|c|}{$1963-1995 \mathrm{~cm} /$ year } & \multicolumn{3}{|c|}{$1979-2005 \mathrm{~cm} /$ year } & \multicolumn{3}{|c|}{ Century $\mathrm{cm} / \mathrm{year}$} \\
\hline & $\mathbf{U}$ & NU & Sig. & $\mathbf{U}$ & NU & Sig. & $\mathbf{U}$ & NU & Sig. & $\mathbf{U}$ & NU & Sig. & $\mathbf{U}$ & NU & Sig. & $\mathbf{U}$ & NU & Sig. & $\mathbf{U}$ & NU & Sig. \\
\hline WF & -0.008 & 0.015 & 0.000 & 0.133 & 0.026 & 0.000 & 2 & 5 & 0.000 & 10 & 1 & 0 & 4 & 35 & .000 & 39 & 64 & 0.000 & 41 & -0.043 & .000 \\
\hline MF & -0.013 & -0.018 & 0.000 & 0.005 & 0.006 & 0.413 & -0.009 & -0.090 & 0.000 & -0.120 & -0.163 & 0.000 & -0.048 & -0.115 & 0.000 & -0.109 & -0.187 & 0.000 & -0.044 & -0.050 & 0.000 \\
\hline DF & -0.007 & -0.016 & 0.000 & -0.040 & -0.052 & 0.000 & -0.274 & -0.270 & 0.389 & 0.025 & -0.002 & 0.000 & -0.182 & -0.162 & 0.000 & -0.066 & -0.064 & 0.467 & -0.042 & -0.069 & 0.000 \\
\hline
\end{tabular}

Table 11. The $100 \mathrm{~m}$ Grid Cell Yearly Average Total Precipitation Trends for each period and its corresponding Urban vs. Non urban T test significance values.

\begin{tabular}{|c|c|c|c|c|c|c|c|c|c|c|c|c|c|c|c|c|c|c|c|c|c|}
\hline & \multicolumn{3}{|c|}{$1900-1929 \mathrm{~cm} /$ year } & \multicolumn{3}{|c|}{$1930-1959 \mathrm{~cm} /$ year } & \multicolumn{3}{|c|}{$1960-1989 \mathrm{~cm} /$ year } & \multicolumn{3}{|c|}{$1990-2007 \mathrm{~cm} /$ year } & \multicolumn{3}{|c|}{$1963-1995 \mathrm{~cm} / \mathrm{year}$} & \multicolumn{3}{|c|}{ 1979-2005 cm/year } & \multicolumn{3}{|c|}{ Century cm/year } \\
\hline & $\mathbf{U}$ & NU & Sig. & $\mathbf{U}$ & NU & Sig. & $\mathbf{U}$ & NU & Sig. & $\mathbf{U}$ & NU & Sig. & $\mathbf{U}$ & NU & Sig. & $\mathbf{U}$ & NU & Sig. & $\mathbf{U}$ & NU & Sig. \\
\hline WF & 0.008 & -0.019 & 0.000 & 0.134 & 0.029 & 0.000 & -0.133 & -0.198 & 0.000 & -0.762 & -0.464 & 0.000 & -0.100 & -0.136 & 0.000 & -0.142 & -0.675 & 0.000 & -0.039 & -0.071 & 0.000 \\
\hline MF & -0.015 & -0.023 & 0.000 & -0.003 & 0.009 & 0.000 & 0.011 & -0.094 & 0.000 & -0.120 & -0.166 & 0.000 & -0.030 & -0.121 & 0.000 & -0.098 & -0.191 & 0.000 & -0.040 & -0.045 & 0.000 \\
\hline $\mathrm{DF}$ & -0.011 & -0.023 & 0.000 & -0.038 & -0.053 & 0.000 & -0.287 & -0.273 & 0.000 & 0.019 & -0.003 & 0.000 & -0.194 & -0.163 & 0.000 & -0.072 & -0.069 & 0.052 & -0.045 & -0.052 & 0.000 \\
\hline
\end{tabular}


Figure 27. Number of study periods recording higher urban vs. non-urban precipitation trends.

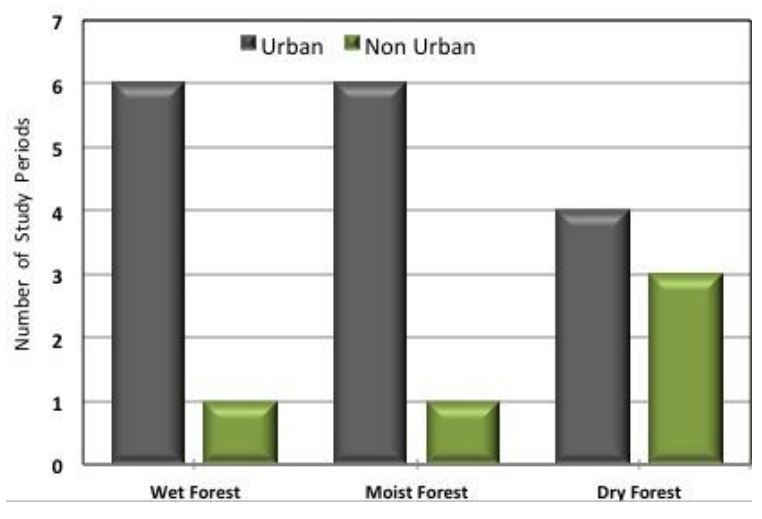

\section{Conclusions}

Precipitation has been decreasing in Puerto Rico for most of the century and in all HELZs, particularly before 1970, a period in which monthly average and median curves are relatively consistent (Figure 3). Seasonally, Wet Season Precipitation amounts have been decreasing in all HELZ through the century but the Dry Forest have been the HELZ with the highest and most notable Dry Season precipitation increase (Figure 18). However, a different pattern emerged after 1970 with average monthly and median precipitation curves showing more separation, particularly in the Dry Forest HELZ. The Dry Forest is the only HELZ where urban precipitation has been increasing recently (Figure 24). This new pattern could well be the effects of new climate or just the first half of the 30 -year period receiving higher precipitation that precedes the second half of the period of decreasing similar to the one that dominates all 30 -year periods of the analysis.

We found evidence that urban development has impacted local precipitation based on an urban effect on local precipitation detected by GIS generated data analysis. However, this impact was not detected directly from station data analysis. Finding some urban impacts from the beginning of the century was unexpected. Some HELZs receive more precipitation over urban areas than over non-urban areas while others behave opposite to this. Further, this relationship is not constant and is reversed in some periods (Tables 8 and 9). Precipitation over urban areas dominates in the Wet Forest while precipitation over non-urban areas dominates in the Dry Forest (Figure 24). These findings were also unexpected. The Wet Forest is mostly forested and urban development is virtually nonexistent, however it may reveal a higher sensitivity or response to urban impacts than other HELZs. On the other hand, the Dry Forest is the driest, warmest and most lightly forested region of the island where urban development is not as intensive and widespread as in the Moist Forest. This condition could increase urban precipitation because of increased surface roughness and convection.

In addition, this work has provided an effective new approach that could be used by small islands to assess LULCC impacts on the local climate. This method could be applied to any climate variable and any land use or land cover type using station dada, GIS tools and analysis of variance.

Future research should consider rainfall intensity variation across landscapes as well as the distinction between types or sources of rainfall. Comparison of long-term climatological changes with insight provided by modeling the impacts of LULCC on individual events may also provide insight into the causes for changes in long-term climatology, but such work is its early stages [48]. Such 
comparisons may also provide a basis for examining the impacts of urbanization on adjacent downwind areas. Radar and satellite studies would also be helpful to examine the scattered nature of rainfall and to address the limitation inherent in working with station data that may not accurately capture the widespread nature of precipitation. In addition, we recommend the use of adjusted and filtered data to isolate locally generated events from synoptic events and standardized land cover vegetation classification for climate and ecological research. Finally, as a next stage in this research, we recommend use of earlier Land Cover maps that have recently come available in digitized form [14]. This would extend the analysis since in the absence of these maps this study assumed that the current urban developed area was unchanged throughout the entire century, resulting in an overestimation of the amount of urban area or pixels that existed at the beginning of the century that may in turn explain some unexpected results for the periods early in the century.

\section{Acknowledgments}

We thank Vose and Williams at NOAA for providing precipitation observation data for 1900-2007 from 139 stations in Puerto Rico. Also, Olga Ramos from the Institute of Tropical Forestry for providing HELZ and other local GIS data, Chris Daly for providing PRISM GIS data and Sigfredo Torres-González from the USGS Caribbean Water Center office for providing rain gage data. Two anonymous referees provided comments that improved the manuscript.

\section{Author Contributions}

Dr. Angel Torres-Valcárcel designed and led implementation of the research as his $\mathrm{PhD}$ dissertation. He completed the literature review, GIS work, data generation, results interpretation, and wrote the draft manuscript. Dr. Jon Harbor oversaw project execution, participated in discussion of the design and results, and assisted with manuscript revision. Cesar González-Aviles and Ana Torres-Valcárcel led selection and implementation of statistical analyses, database quality control, and reviewed the results, discussion, and conclusions to ensure consistent and appropriate use of statistics.

\section{Conflicts of Interest}

The authors declare no conflict of interest.

\section{References}

1. Kalnay, E.; Cai, M. Impact of urbanization and land-use change on climate. Nature 2003, 423, 528-531.

2. Vose, R.S.; Easterling, D.R.; Gleason, B. Maximum and minimum temperature trends for the globe: An update through 2004. Geophys. Res. Lett. 2005, 32, doi:10.1029/2005GL024379.

3. Ezber, Y.; Lutfi Sen, O.; Kindap, T.; Karaca, M. Climatic effects of urbanization in Istanbul: A statistical and modeling analysis. Int. J. Climatol. 2007, 27, 667-679.

4. Pielke, R.A.; Adegoke, J.; Beltran-Przekurat, A.; Hiemstra, C.A.; Lin, J.; Nair, U.S.; Niyogi, D.; Nobis, T.E. An overview of regional land use and land cover impacts on rainfall. Tellus $B \mathbf{2 0 0 7}$, 59, 587-601. 
5. Pitman, A.J.; de Noblet-Ducoudré, N.; Cruz, F.T.; Davin, E.L.; Bonan, G.B.; Brovkin, V.; Claussen, M.; Voldoire, A. Uncertainties in climate responses to past land cover change: First results from the LUCID intercomparison study. Geophys. Res. Lett. 2009, 36, doi:10.1029/2009GL039076.

6. Shepherd, J. Impacts of Urbanization on Precipitation and Storms: Physical Insights and Vulnerabilities. In Climate Vulnerability; Pielke, R., Ed.; Elsevier: Amsterdam, Holland, 2013; pp. 109-125.

7. Niyogi, D.; Pyle, P.; Lei, M.; Arya, S.; Kishtawal, C.; Shepherd, J.; Chen, F.; Wolfe, B. Urban modification of thunderstorms-An observational storm climatology and model case study for the Indianapolis urban region. J. Appl. Meteor. Clim. 2011, 50, 1129-1144.

8. Velazquez-Lozada, A.; Gonzalez, J.E.; Winter, A. Urban heat island effect analysis for San Juan, Puerto Rico. Atmos. Environ. 2006, 40, 1731-1741.

9. Jauregui, E.; Romales, E. Urban effects on convective precipitation in Mexico City. Atmos. Environ. 1996, 30, 3383-3389.

10. Stewart, I.D.; Oke, T. Classifying Urban Climate Field Sites by "Local Climate Zones": The Case of Nagano, Japan. In Proceedings of Seventh International Conference on Urban Climate, Yokohama, Japan, 29 June-3 July 2009.

11. Imhoff, M.L.; Zhang, P.; Wolfe, R.E.; Bounoua, L. Remote sensing of the urban heat island effect across biomes in the continental USA. Remote Sens. Environ. 2010, 114, 504-513.

12. Murphy, D.J.; Hall, M.H.; Hall, C.A.; Heisler, G.M.; Stehman, S.V.; Anselmi-Molina, C. The relationship between land cover and the urban heat island in northeastern Puerto Rico. Int. J. Climatol. 2011, 31, 1222-1239.

13. Torres, A.R.; Harbor, J.; Torres, A.L.; González, C. The impacts of land use/land cover change on temperature patterns in Puerto Rico. Int. J. Climatol. 2014, under review.

14. Comarazamy, D.E.; González, J.E.; Luvall, J.C.; Rickman, D.L.; Bornstein, R.D. Climate impacts of land-cover and land-use changes in tropical islands under conditions of global Climate change. J. Clim. 2013, 26, 1535-1550.

15. Van der Molen, M.K. Meteorological Impacts of Land Use Change in the Maritime Tropics. Ph.D. Thesis, Vrije Universiteit, Amsterdam, The Netherlands, 2002.

16. Kishtawal, C.; Niyogi, D.; Tewari, M.; Pielke, R.; Shepherd, J. Urbanization signature in the observed heavy rainfall climatology over India. Int. J. Climatol. 2009, 30, 1908-1916.

17. Neelin, J.D.; Münnich, M.; Su, H.; Meyerson, J.E.; Holloway, C.E. Tropical drying trends in global warming models and observations. PNAS 2006, 103, 6110-6115.

18. Claussen, M.; Brovkin, V.; Ganopolski, A. Biogeophysical versus biogeochemical feedbacks of large-scale land cover change. Geophys. Res. Lett. 2001, 28, 1011-1014.

19. Fall, S.; Niyogi, D.; Semazzi, F. Analysis of mean climate conditions in Senegal (1971-98). Earth Interact. 2006, 10, 1-40.

20. Ewel, J.; Whitmore, J. The Ecological Life Zones of Puerto Rico and US Virgin Islands; Forest Service Research Paper ITF-18. Institute of Tropical Forestry: Rio Piedras, PR, USA, 1973.

21. Daly, C.; Helmer, E.H.; Quinones, M. Mapping the climate of Puerto Rico, Vieques, and Culebra. Int. J. Climatol. 2003, 23, 1359-1381.

22. Carter, M.M.; Elsner, J.B. Convective rainfall regions of Puerto Rico. Int. J. Climatol. 1996, 16, 1033-1043. 
23. Carter, M.M.; Elsner, J.B. A statistical method for forecasting rainfall over Puerto Rico. Weather Forecast. 1997, 12, 515-525.

24. Malmgren, B.; Winter, A. Climate Zonation in Puerto Rico based on multivariate statistical analysis and an artificial neural network. J. Clim. 1999, 12, 977-985.

25. Jury, M.; Malmgren, B.A.; Winter, A. Subregional precipitation climate of the Caribbean and relationships with ENSO and NAO. J. Geophys. Res.: Atmos. (1984-2012) 2007, 112, doi:10.1029/2006JD007541.

26. Pagan-Trinidad, I. Statistical Analyses of Spatial and Temporal Storm Rainfall Characteristics in Puerto Rico; Project No. 374103 Final Technical Report; United States Department of Interior: Mayaguez, PR, USA, 1984.

27. Ramirez-Beltran, N.D.; Lau, W.K.; Winter, A.; Castro, J.M.; Escalante, N.R. Empirical probability models to predict precipitation levels over Puerto Rico stations. Mon. Weather Rev. 2007, 135, 877-890.

28. Comarazamy, D.E.; González, J.E. On the validation of the simulation of early season precipitation on the island of Puerto Rico using a mesoscale atmospheric model. J. Hydrometeorol. 2008, 9, 507-520.

29. Ray, C.L. Wet and dry periods in Puerto Rico, 1899-1932. Mon. Weather Rev. 1933, 61, 222-223.

30. Malmgren, B.; Winter, A.; Chen, D. El Niño-Southern Oscillation and North Atlantic Oscillation control of the Puerto Rico climate. J. Clim. 1998, 11, 2713-2717.

31. Larsen, M.C. Analysis of 20th century rainfall and streamflow to characterize drought and water resources in Puerto Rico. Phys. Geogr. 2000, 21, 494-521.

32. Comarazamy, D.E. Atmospheric Modeling of Caribbean Region: Precipitation and Wind Analysis in Puerto Rico for April 1998. Master's Thesis, University of Puerto Rico, PR, USA, 2001.

33. Chen, A.A.; Taylor, M.A. Investigating the link between early season Caribbean rainfall and the El Niño+ 1 year. Int. J. Climatol. 2002, 22, 87-106.

34. Nyberg, J.; Malmgren, B.A.; Winter, A.; Jury, M.R.; Kilbourne, K.H.; Quinn, T.M. Low Atlantic hurricane activity in the 1970s and 1980s compared to the past 270 years. Nature 2007, 447, 698-701.

35. Harmsen, E.W.; Miller, N.L.; Schlegel, N.J.; Gonzalez, J.E. Seasonal climate change impacts on evapotranspiration, precipitation deficit and crop yield in Puerto Rico. Agric. Water Manag. 2009, 96, 1085-1095.

36. Jury, M.R. An intercomparison of observational, reanalysis, satellite, and coupled model data on mean rainfall in the Caribbean. J. Hydrometeorol. 2009, 10, 413-430.

37. Jury, M.R.; Sanchez, D.M. Composite meteorological forcing of Puerto Rican springtime flood events. Weather Forecast. 2009, 24, 262-271.

38. Comarazamy, D.E.; González, J.E.; Luvall, J.C.; Rickman, D.L.; Mulero, P.J. A land-atmospheric interaction study in the coastal tropical city of San Juan, Puerto Rico. Earth Interact. 2010, 14, 1-24.

39. Angeles, M.E.; González, J.E.; Ramírez-Beltrán, N.D.; Tepley, C.A.; Comarazamy, D.E. Origins of the Caribbean rainfall bimodal behavior. J. Geophys. Res. Atmos. (1984-2012) 2010, 115, doi:10.1029/2009JD012990.

40. Comarazamy, D.E.; González, J.E. Regional long-term climate change (1950-2000) in the midtropical Atlantic and its impacts on the hydrological cycle of Puerto Rico. J. Geophys. Res. Atmos. (1984-2012) 2011, 116, doi:10.1029/2010JD015414. 
41. Helmer, E.H.; Ramos, O.; del MLópez, T.; Quiñónez, M.; Diaz, W. Mapping the forest type and land cover of Puerto Rico, a component of the Caribbean biodiversity hotspot. Caribb. J. Sci. 2002, 38, 165-183.

42. Gould, W.; Alarcón, C.; Fevold, B.; Jiménez, M.E.; Martinuzzi, S.; Potts, G.; Solórzano, M.; Ventosa, E. Puerto Rico Gap Analysis Project-Final Report; USGS, Moscow, Idaho and the USDA Forest Service International Institute of Tropical Forestry: Río Piedras, PR, USA, 2007.

43. Magaña, V.; Amador, J.A.; Medina, S. The midsummer drought over Mexico and Central America. J. Clim. 1999, 12, 1577-1588.

44. Curtis, S.; Gamble, D.W. Regional variations of the Caribbean midsummer drought. Theor. Appl. Climatol. 2007, doi:10.1007/s00704-007-0342-0.

45. Gamble, D.W.; Parnell, D.B.; Curtis, S. Spatial variability of the Caribbean midsummer drought and relation to the North Atlantic High. Int. J. Climatol. 2008, 28, 343-350.

46. Holdridge, L.R. Life Zone Ecology; Tropical Science Center: San Jose, Costa Rica, 1967.

47. Angeles, M.E.; Gonzalez, J.E.; Erickson, D.J., III; Hernández, J.L. Predictions of future climate change in the Caribbean region using global general circulation models. Int. J. Climatol. 2007, 27, 555-569.

48. Torres-Valcárcel, A. The Impact of Land Use and Land Cover Changes on the Tropical Maritime Climate of Puerto Rico. Ph.D. Thesis, Purdue University, West Lafayette, IN, USA, 2013.

(C) 2014 by the authors; licensee MDPI, Basel, Switzerland. This article is an open access article distributed under the terms and conditions of the Creative Commons Attribution license (http://creativecommons.org/licenses/by/3.0/). 